\title{
Neuroanatomical Distribution of the Serotonergic System in the Brain and Retina of Holostean Fishes, The Sister Group to Teleosts
}

\author{
Daniel Lozano Agustín González Jesús M. López \\ Department of Cell Biology, Faculty of Biology, University Complutense, Madrid, Spain
}

\section{Keywords}

Serotonin · Immunohistochemistry · Epiphysis · Raphe column · Lepisosteus · Atractosteus · Amia · Brain evolution

\begin{abstract}
Among actinopterygian fishes, holosteans are the phylogenetically closest group to teleosts but they have been much less studied, particularly regarding the neurochemical features of their central nervous system. The serotonergic system is one of the most important and conserved systems of neurotransmission in all vertebrates. By means of immunohistochemistry against serotonin (5-hydroxytryptamine), we have conducted a comprehensive and complete description of this system in the brain and retina of representative species of the 3 genera of holostean fishes, belonging to the only 2 extant orders, Amiiformes and Lepisosteiformes. Serotonin-immunoreactive cell groups were detected in the preoptic area, the hypothalamic paraventricular organ, the epiphysis, the pretectal region, the long and continuous column of the raphe, the spinal cord, and the inner nuclear layer of the retina. Specifically, the serotonergic cell groups in the preoptic area, the epiphysis, the pretectum, and the retina had never been identified in previous studies in this
\end{abstract}

group of fishes. Widespread serotonergic innervation was observed in all main brain regions, but more abundantly in the subpallium, the hypothalamus, the habenula, the optic tectum, the so-called cerebellar nucleus, and the area postrema. The comparative analysis of these results with those in other groups of vertebrates reveals some extremely conserved features, such as the presence of serotonergic cells in the retina, the pineal organ, and the raphe column, while other characteristics, like the serotonergic populations in the preoptic area, the paraventricular organ, the pretectum, and the spinal cord are generally present in all fish groups, but have been lost in most amniotes.

(c) 2020 S. Karger AG, Basel

\section{Introduction}

In the early Permian (approx. 300 million years ago), neopterygian fishes, which together with cladistians and chondrosteans constitute the actinopterygian group of bony fishes, diverged into the sister groups of teleosts and holosteans. Teleosts constitute the largest and most diverse group of vertebrates (over 30,000 species) and have been widely studied in neurobiology, whereas holosteans

\section{KARGER}

(c) 2020 S. Karger AG, Basel

karger@karger.com

www.karger.com/bbe
Dr. Jesús M. López

Departamento de Biología Celular

Facultad de Biología, Universidad Complutense

ES-28040 Madrid (Spain)

jmlredondo@bio.ucm.es 
form a small group with only 8 species that have been scarcely studied [Hughes et al., 2018]. In the late Permian (approx. 270 million years ago), holosteans separated into 2 orders, Amiiformes with the single extant species Amia calva (bowfin), and Lepisosteiformes (gars), which separated into the genera Lepisosteus (4 living species) and Atractosteus (3 living species) in the Cretaceous (approx. 100 million years ago) [Wright et al., 2012; Nelson et al., 2016; Betancur-R et al., 2017; Hughes et al., 2018]. Specifically, the research of the nervous system organization of this small group of fishes has been classically neglected in favor of its sister group. Only the visual and lateral-line systems [Northcutt and Butler, 1976, 1980; McCormick, 1981; Song and Northcutt, 1991a, b; Butler and Northcutt, 1992; Collin and Northcutt, 1995] and some neurotransmitter systems [Parent and Northcutt, 1982; Chiba and Oka, 1999; Malz et al., 1999; Baker and Bird, 2002; Chiba, $2005,2007]$ had been studied before our research group initiated a program to delve more deeply into the neuroanatomical features of holosteans. Thus, we have thoroughly analyzed the cholinergic, nitrergic, orexinergic and, recently, the catecholaminergic systems [Morona et al., 2013; López et al., 2017; Lozano et al., 2018, 2019], in addition to the brain distribution of specific transcription factors in order to identify the basal ganglia structures in the subpallium [González et al., 2014]. However, although the serotonergic system is one of the most important brain neurotransmitter systems, it has not been fully analyzed in species representative of the 2 orders of the group.

The monoamine serotonin (5-hydroxytryptamine; $5-\mathrm{HT}$ ) is mainly produced in neurons located in the brainstem whose widespread projections reach virtually all parts of the central nervous system (CNS). Due to this extensive innervation, 5-HT is involved in many brain functions, such as motor activity, mood, sleep, aggressiveness, fear, appetite, vascular function, nociception, and sexual behavior [Edwards and Kravitz, 1997; Jacobs and Fornal, 1997; Lucki, 1998; Müller and Jacobs, 2010]. The serotonergic system was initially visualized by the formaldehyde-induced fluorescence method [Dahlström and Fuxe, 1964] and later, with the development of antibodies against 5-HT [Steinbusch, 1981], the modern immunohistochemical methods quickly provided more detailed and reliable information about the conserved features of this system in amniotes (primates: Schofield and Everitt [1981]; Baker et al. [1991a, b]; monotremes: Manger et al. [2002]; rodents: Steinbusch [1981]; Törk [1990]; birds: Meneghelli et al. [2009]; reptiles: Ueda et al. [1983]; Smeets and Steinbusch [1988]; Bennis et al. [1990]; Challet et al. [1991]) and anamniotes (amphibians: Ueda et al. [1984];
Corio et al. [1992]; Clairambault et al. [1994]; lungfishes: López and González [2015]; teleosts: Kaslin and Panula [2001]; Rink and Guo [2004]; chondrosteans: Adrio et al. [1999]; cladistians: López and González [2014]; cartilaginous fishes: Stuesse et al. [1995]; Carrera et al. [2008]; jawless fishes: Pierre et al. [1992]; Antri et al. [2006]; CornidePetronio et al. [2013]). Of note, the available information on the serotonergic system in holostean fishes is not complete and was obtained by the formaldehyde-induced fluorescence method [Parent and Northcutt, 1982], although fragmentary data obtained by immunohistochemistry have also been reported [Onstott and Elde, 1986; Chiba and Oka, 1999; Chiba, 2007; Wai et al., 2007]. Therefore, in this comprehensive study we have analyzed this important neurotransmitter system by means of highly sensitive immunohistochemical methods in the CNS of 4 representative species of the 3 genera of holostean fishes: A. calva, L. platyrhincus, L. oculatus, and A. spatula. The serotonergic cells and fibers were detected using a specific antibody against 5-HT, which was also combined in double immunolabeling experiments with tyrosine hydroxylase (TH) and nitric oxide synthase (NOS) for a more accurate interpretation of the results. Moreover, following the current neuromeric model of brain regionalization [Gilland and Baker, 1993; Puelles and Rubenstein, 2003, 2015; Aroca and Puelles, 2005; Straka et al., 2006], the analysis of the serotonergic structures in holosteans has been carried out in comparison with data reported in similar studies of other vertebrates, with emphasis on fishes, in order to assess specific and conserved features in the evolution of this neurotransmitter system.

\section{Materials and Methods}

For the present study, 18 young adult gars, $9-18 \mathrm{~cm}$ in length (6 spotted gars, L. oculatus, 7 Florida gars, L. platyrhincus, and 5 alligator gars, A. spatula), and 3 adult bowfins, $A$. calva, $28-35 \mathrm{~cm}$ in length, were used. The animals were obtained from licensed suppliers (PezyCia, Madrid, Spain, and DNATecosistemas, Madrid, Spain) and were maintained in aquaria with controlled temperature $\left(24-28^{\circ} \mathrm{C}\right)$ and natural light conditions. The original research reported herein was performed according to the regulations and laws established by the European Union (2010/63/EU) and Spain (Royal Decree 53/2013) for the care and handling of animals in research and after approval from the Complutense University to conduct the experiments described.

The animals were deeply anesthetized by immersion in $0.1-$ $0.2 \%$ tricaine methanesulfonate solution (MS222, Sandoz, Basel, Switzerland; $\mathrm{pH} 7.3$ ) and perfused transcardially with physiological saline followed by $100-150 \mathrm{~mL}$ of cold $4 \%$ paraformaldehyde in a $0.1 \mathrm{M}$ phosphate buffer (PB, pH 7.4). The brain, eyes, and the spinal cord were removed and kept in the same fixative for $2-3 \mathrm{~h}$. Subse-
26

Brain Behav Evol 2020;95:25-44 DOI: $10.1159 / 000505473$
Lozano/González/López 


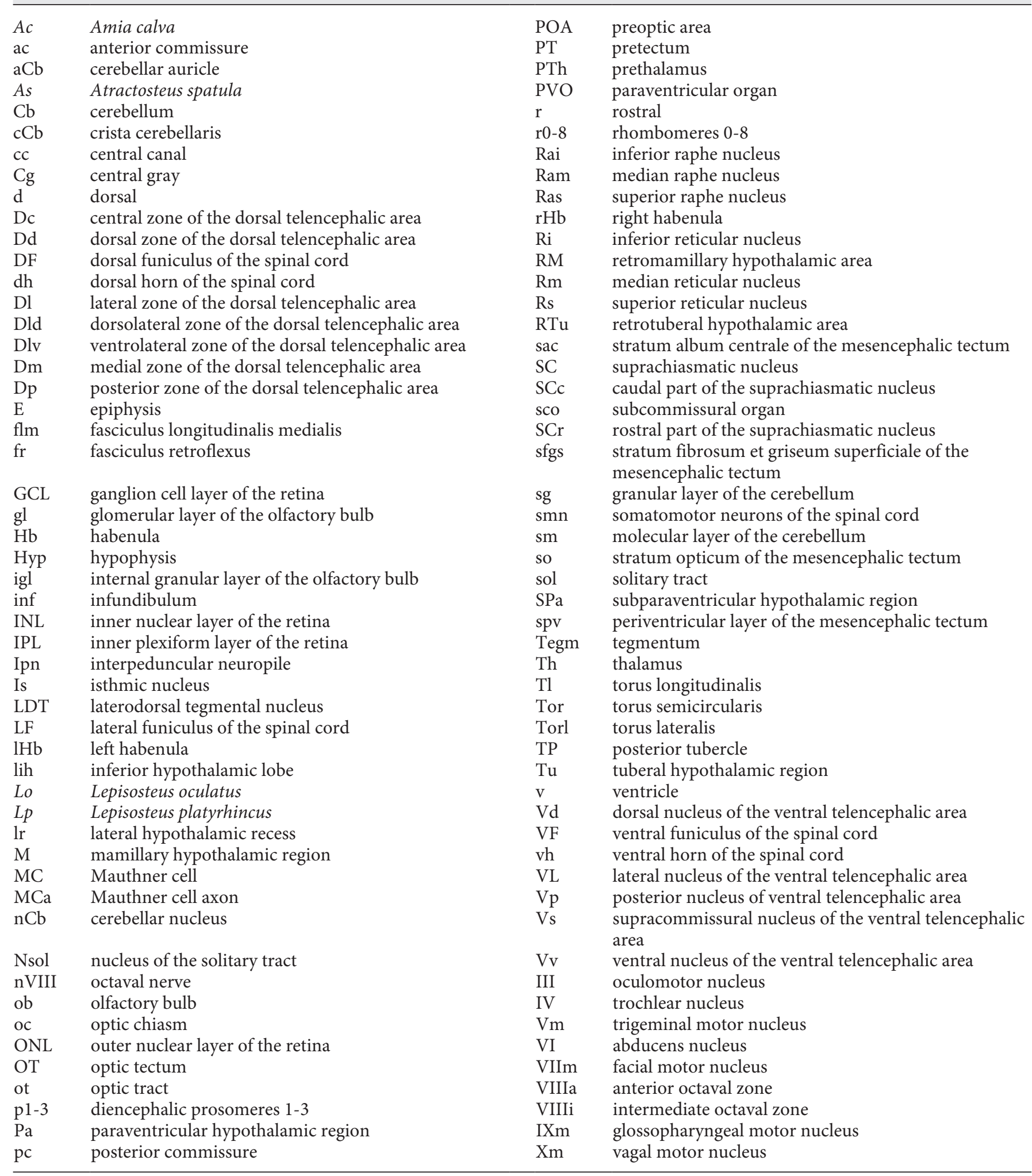




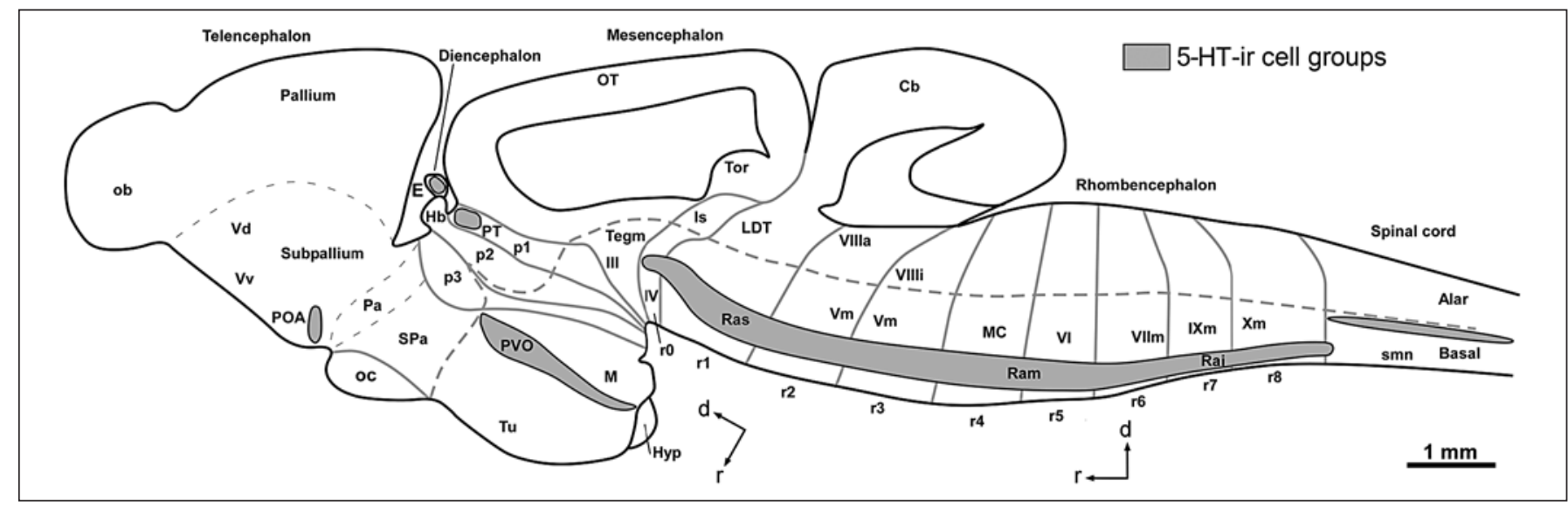

Fig. 1. Schematic reconstruction of the sagittal series of sections of the brain showing the locations of the serotonergic (5-HT-ir) cell groups in L. platyrhincus, according to a segmental interpretation of the brain. Note that the coordinate system rotates almost $90^{\circ}$ because the longitudinal axis of the brain bends in the diencephalon and, therefore, classically interpreted ventral regions in the diencephalon and hypothalamus are actually rostral regions, whereas the classically dorsal regions are caudal (according to the current prosomeric model) [Puelles and Rubenstein, 2003, 2015].

quently, they were immersed in a solution of $30 \%$ sucrose in PB for $4-6 \mathrm{~h}$ at $4{ }^{\circ} \mathrm{C}$ until they sank, and were then embedded in a solution of $20 \%$ gelatin with $30 \%$ sucrose in PB, and stored for $6 \mathrm{~h}$ in a $10 \%$ formaldehyde solution at $4{ }^{\circ} \mathrm{C}$. The brain, spinal cord, and eyes were cut on a freezing microtome $(30-40 \mu \mathrm{m})$ in the transverse or sagittal plane, and sections were collected and rinsed in cold PB.

\section{5-HT Immunohistochemistry}

The free-floating sections were rinsed twice in $\mathrm{PB}$, treated with $1 \% \mathrm{H}_{2} \mathrm{O}_{2}$ in $\mathrm{PB}$ for 15 min to reduce endogenous peroxidase activity, rinsed again 3 times in $\mathrm{PB}$, and processed by the peroxidase antiperoxidase (PAP) method [Sternberger, 1979]. This included a first incubation of the sections in rabbit anti-5-HT (ImmunoStar, diluted 1:1,000). The dilution of the antibodies was made in PB containing $0.5 \%$ Triton X-100 (PBS-T), 15\% normal goat serum, and $2 \%$ bovine serum albumin, for $48 \mathrm{~h}$ at $4{ }^{\circ} \mathrm{C}$. Subsequently, the sections were rinsed 3 times in $\mathrm{PB}$ for $10 \mathrm{~min}$ and incubated for 60 $\mathrm{min}$ at room temperature in goat anti-rabbit (Dakopatts), diluted 1:50. After rising again 3 times for $10 \mathrm{~min}$ each, the sections were incubated for $90 \mathrm{~min}$ in rabbit PAP complex (Dakopatts), diluted 1:500. The secondary antiserum and the PAP complex were diluted in $\mathrm{PB}$ containing $0.5 \%$ Triton X-100, 15\% normal goat serum, and $2 \%$ bovine serum albumin. Finally, the sections were rinsed 3 times for 10 min each in $\mathrm{PB}$ and subsequently stained in $0.5 \mathrm{mg} / \mathrm{mL} 3,3^{\prime}$-diaminobenzidine (DAB; Vector SK4100) intensified with nickel [Adams, 1981], with $0.01 \% \mathrm{H}_{2} \mathrm{O}_{2}$ in $\mathrm{PB}$ for $1-3$ min. Transverse and sagittal series were mounted on glass slides with $0.25 \%$ gelatin in $0.1 \mathrm{M}$ Tris- $\mathrm{HCl}$ buffer $(\mathrm{TB}, \mathrm{pH} 7.6)$ and, after dehydration, coverslipped with Entellan (Merck, Darmstadt, Germany). Some sections were counterstained with cresyl violet to facilitate the analysis of the results.

\section{Double 5-HT and TH or NOS Immunolabeling}

To compare the localization of the serotonergic elements with catecholaminergic and nitrergic structures, a procedure based on double immunolabeling was used as follows: (1) first incubation for $72 \mathrm{~h}$ at $4^{\circ} \mathrm{C}$ in a mixture of rabbit anti-5-HT (ImmunoStar, diluted 1:1,000) with mouse anti-TH (ImmunoStar; diluted 1:1,000) or sheep anti-NOS (K205 antibody, kindly donated by Dr. Piers Emson, diluted 1:20,000); (2) second incubation for $90 \mathrm{~min}$ at room temperature in a mixture of secondary antisera: Alexa 594-conjugated chicken anti-rabbit serum (red fluorescence; diluted 1:300; Molecular Probes; catalogue reference: A21441) and Alexa 488-conjugated chicken anti-mouse serum (green fluorescence; diluted 1:300; Molecular Probes; catalogue reference A21200) or Alexa 488-conjugated donkey anti-goat serum (green fluorescence; diluted 1:300; Molecular Probes; catalogue reference: A32814). After rinsing 3 times in PB, the sections were mounted on glass slides and coverslipped with VectaShield (Vector, Burlingame, CA, USA) or UltraCruz ${ }^{\mathrm{TM}}$ mounting medium containing DAPI (4',6-diamidino-2-phenylindole) for fluorescent labeling of DNA (sc-24941; Santa Cruz Biotechnology).

\section{Controls and Specificity of the Antibodies}

The specificity of the antibodies used in our study has been assessed by the commercial companies who manufactured them and previously described in holostean fishes [Morona et al., 2013; López et al., 2017; Lozano et al., 2018, 2019]. In addition, there were 2 general controls for the immunohistochemical reaction: (1) staining some selected sections with preimmune normal serum, and (2) controls in which either the primary and/or the secondary antibody or the PAP complex was omitted. In all these negative controls, the immunostaining was eliminated. The antibodies used

Fig. 2. a-r Diagrams of transverse sections through the brain of $L$. platyrhincus at the levels indicated in the lateral view of the brain. 5-HT-ir cell bodies (large dots) and fibers (small dots, wavy lines) are represented in the left half of each section. For abbreviations, see list. Scale bar, $1 \mathrm{~mm}$.
(For figure see next page.) 

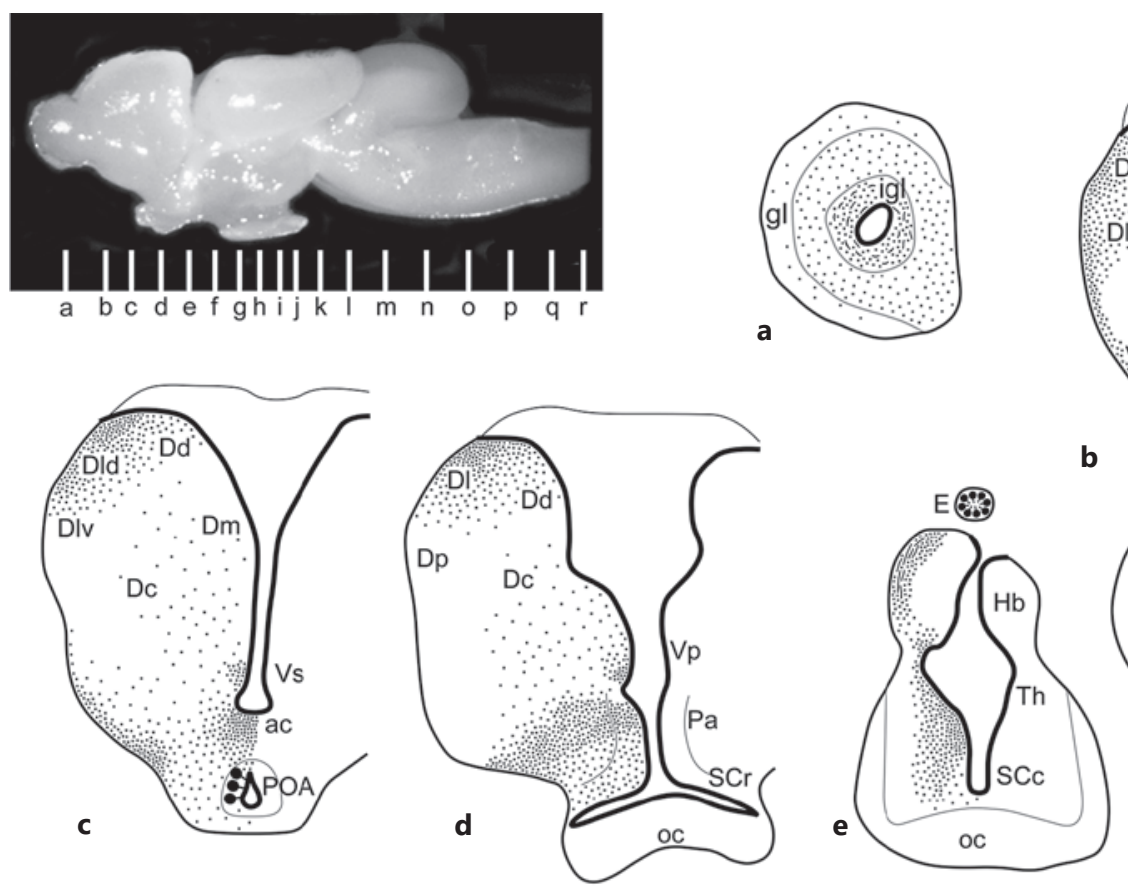

b
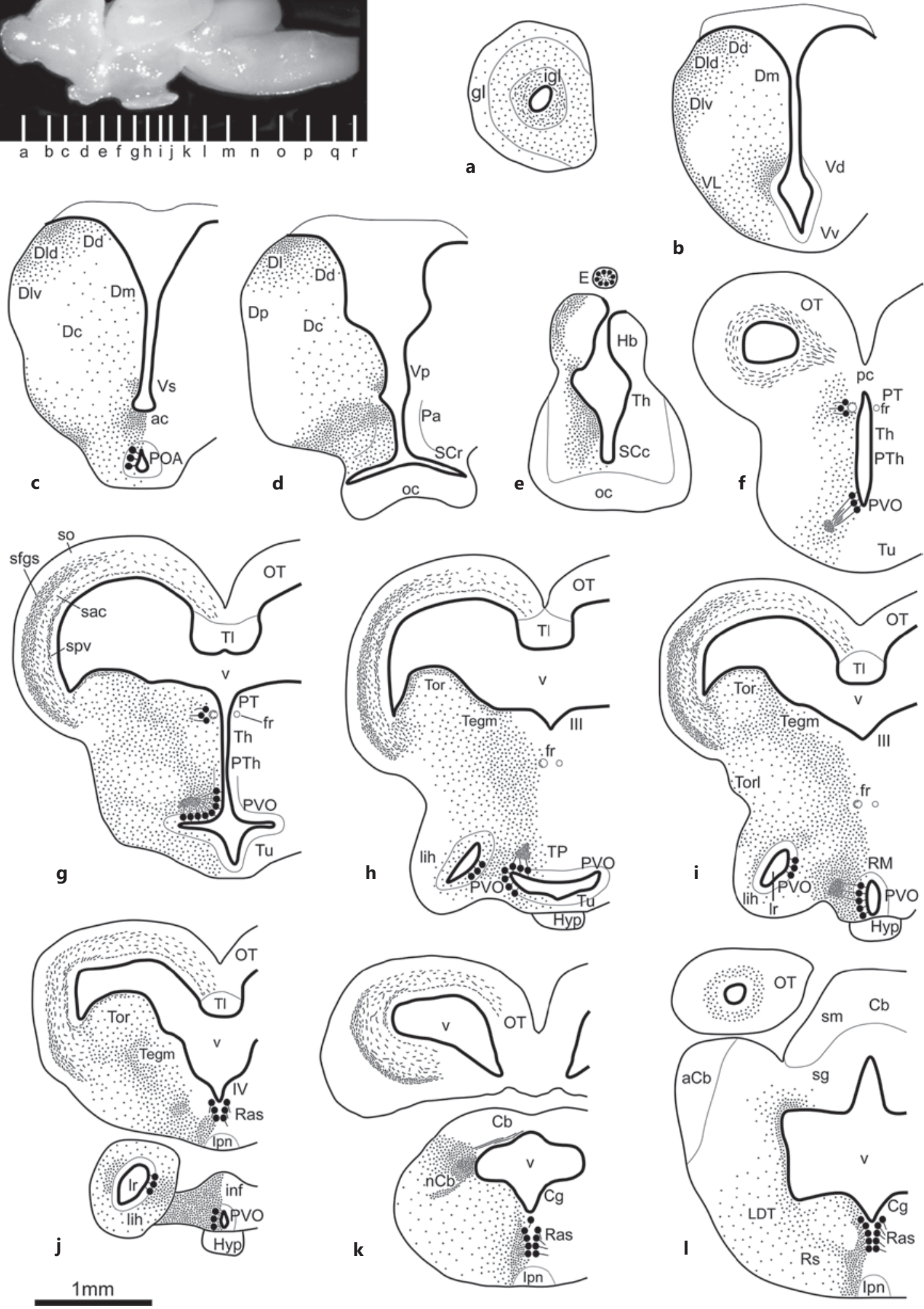

(Figure continued on next page.) 


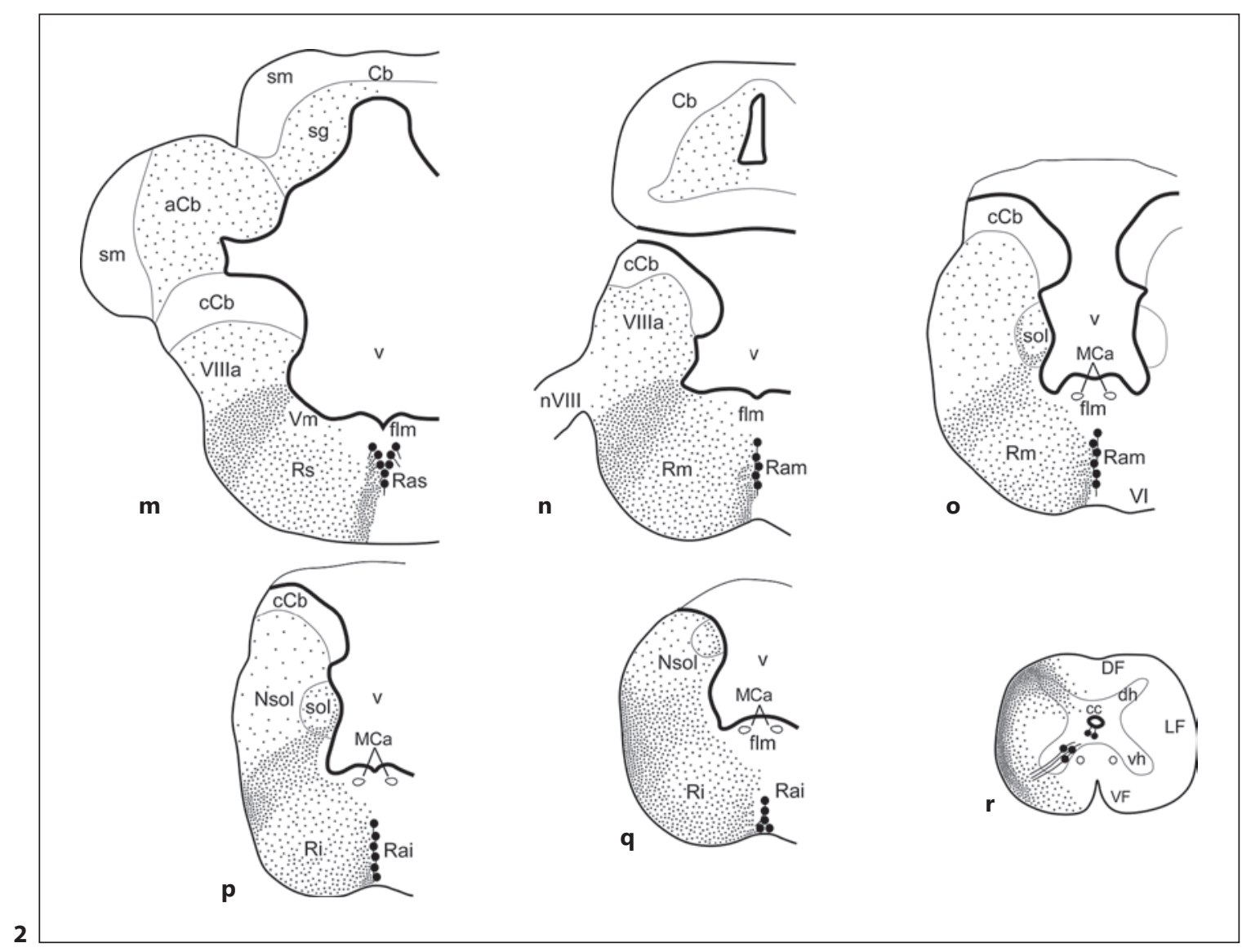

were tested, under identical conditions, in tissues devoid of antigen, as a negative control, and in tissues positive for the antibodies. In all cases these produced satisfactory results.

\section{Evaluation and Presentation of the Results}

The groups of 5-HT-immunoreactive (5-HT-ir) neurons detected in the present study are summarized for the case of L. platyrhincus in a sagittal schematic drawing, with special reference to the neuromeric regionalization of the brain (Fig. 1). In addition, the distribution of 5-HT-ir cell bodies and fibers in the brain was carefully analyzed and the pattern of labeling was charted in representative transverse sections of L. platyrhincus, from rostral to caudal levels (Fig. 2). Drawings were made by means of a camera lucida in which the sections counterstained with cresyl violet facilitated the interpretation of the localization of the labeled structures. The sections were analyzed in both the single- and double-labeled sections with an Olympus BX51 microscope equipped with a digital camera (Olympus DP70) and representative photomicrographs of brain regions with significant labeling were taken and are presented in Figures 3-6. Contrast and brightness were adjusted in Adobe Photoshop CS4 (Adobe Systems, San Jose, CA, USA) and the figures were mounted in Canvas 11 (ACS System International).

The nomenclature is the same as that used in our previous studies with holosteans [Morona et al., 2013; López et al., 2017; Lozano et al., 2018, 2019], which essentially follows previously used terms in these species [Northcutt, 1982; Parent and Northcutt, 1982; Song and Northcutt, 1991a, b; Butler and Northcutt, 1992; North- cutt and Butler, 1993; Heijdra and Nieuwenhuys, 1994; Collin and Northcutt, 1995; Meek and Nieuwenhuys, 1998; Chiba and Oka, 1999; Baker and Bird, 2002; Chiba, 2005], but incorporating the terminology of the prosomeric model for the forebrain [Puelles and Rubenstein, 2003, 2015].

\section{Results}

The antibody against 5-HT used in this study revealed patterns of immunoreactivity that were largely similar for the 4 species of holostean fishes analyzed. As in other vertebrates studied, 5-HT-ir cells were found in distinct groups in the forebrain and brainstem (represented in Fig. 1 according to the neuromeric framework), and a widespread fiber distribution was observed in almost all brain regions. The localization of the 5-HT system was mapped on schematic drawings of transverse sections from the olfactory bulb to the spinal cord, taking L. platyrhincus as the model species for which the complete pattern is detailed (Fig. 2). The results obtained are also summarized in the Table 1, which includes the small species differences observed in particular brain regions. 
In the following sections, we describe the rostrocaudal regional distribution of the 5-HT-ir cell bodies and fibers framed within the segmental organization of the brain, considering the main subdivisions of the forebrain (telencephalon, hypothalamus, and diencephalon), midbrain (mesencephalon), hindbrain (cerebellum and rhombencephalon), and spinal cord (shown in Fig. 3, 4). The sections doubly labeled for 5-HT and TH or NOS were used to corroborate the precise location of the cell groups in the brain and to establish some neurochemical features of the 5-HT-ir cells (Fig. 5, 6).

\section{Forebrain}

The olfactory bulbs, in the most rostral part of the telencephalon, showed conspicuous serotonergic innervation in the inner granular layer of all the species studied (Fig. 2a, 3a) [nomenclature after Meek and Nieuwenhuys, 1998]. Some of these 5-HT-ir fibers were observed very close to the dopaminergic cells located in the same layer and might contact them, as double immunolabeling experiments suggested (Fig. 5a). The pallium of the 4 species of holosteans studied exhibited the characteristic eversion that is common in actinopterygian fishes, although the pallium of Amia is everted to a much greater extent than in gars [Braford, 2009; Nieuwenhuys, 2011]. In gars, moderate distribution of 5-HT-ir fibers was observed mainly in the periventricular layer of the dorsal and lateral areas of the dorsal telencephalic area, with fewer fibers reaching the central and medial areas (Fig. 2b-d, 3b). In Amia, labeled fibers in the pallium were less conspicuous and extended more ventrolaterally in the large dorsal and lateral areas [after Nieuwenhuys, 2011]. The subpallium showed more serotonergic innervation than the pallial areas. A moderate density of fibers was observed in the ventral, lateral, supracommissural, and posterior parts of the ventral telencephalic area ( Vv, VL, Vs, and Vp, respectively), whereas a greater density was noted in its dorsal part (Vd; Fig. 2b-d, 3b-e). Of note, the dopaminergic cell group located in Vd [Lozano et al., 2019] was profusely innervated by 5 -HT-ir fibers (Fig. 5b).

The preoptic area was classically included in the hypothalamus, but it is currently considered the most rostroventral part of the telencephalon (ventrocaudal in classical transverse sections), in the non-evaginated telencephalon impar (in prosomeric view) [Moreno and González, 2011]. In this area of the brain, a 5-HT-ir group of periventricular cerebrospinal fluid (CSF)-contacting cells was observed, and in double labeled sections it was seen that they were located dorsal to the recently described do-
Table 1. Comparative localization and relative abundance of 5-HT-ir cells and fibers in the CNS of the holostean fishes studied

$\frac{\text { Gars }}{\mathrm{C} \quad \mathrm{F}} \frac{\text { Bowfin }}{\mathrm{C}} \mathrm{F}$

Forebrain telencephalon

Olfactory bulb

Pallial areas $\mathrm{Dl}$ and $\mathrm{Dd}$

Pallial areas Dm and DC

Subpallial area $\mathrm{Vd}$

Subpallial area $\mathrm{Vv}$

Subpallial area VL

Subpallial areas Vs and Vp

Preoptic area

Hypothalamus

Paraventricular region

Subparaventricular region

Tuberal region

Paraventricular organ

Mamillary and retromamillary regions

Hypophysis

Diencephalon

Prethalamus

Posterior tubercle

Epiphysis

Habenula

Thalamus

Pretectum

Midbrain

Optic tectum

Torus semicircularis

Torus longitudinalis

Torus lateralis

Mesencephalic tegmentum

Hindbrain

Central gray

Interpeduncular nucleus

Cerebellum

Cerebellar nucleus

Octavolateral area

Laterodorsal tegmental nucleus

Reticular formation

Superior raphe nucleus

Median raphe nucleus

Inferior raphe nucleus

Nucleus of the solitary tract

Area postrema

Spinal cord

Retina

$\begin{array}{llll}- & +++ & - & +++ \\ - & ++ & - & ++ \\ - & + & - & + \\ - & +++ & - & +++ \\ - & ++ & - & ++ \\ - & ++ & - & ++ \\ - & ++ & - & ++ \\ ++ & ++ & ++ & ++ \\ & & & \\ - & +++ & - & ++ \\ - & ++ & - & + \\ - & ++ & - & + \\ +++ & +++ & +++ & +++ \\ - & ++ & - & ++ \\ - & - & - & - \\ & & & \\ - & ++ & - & ++ \\ - & + & - & + \\ +++ & + & +++ & + \\ - & +++ & - & ++ \\ - & ++ & - & ++ \\ ++ & ++ & ++ & ++ \\ & & & \\ - & +++ & - & ++ \\ - & ++ & - & + \\ - & - & - & - \\ - & + & - & + \\ - & ++ & - & ++ \\ & & & \\ - & + & - & + \\ - & + & - & + \\ - & ++ & - & ++ \\ - & +++ & - & +++ \\ - & + & - & + \\ - & + & - & + \\ - & ++ & - & ++ \\ +++ & ++ & +++ & ++ \\ ++ & ++ & ++ & ++ \\ ++ & ++ & ++ & ++ \\ - & ++ & - & + \\ - & +++ & - & ++ \\ ++ & ++ & ++ & ++ \\ ++ & + & ++ & +\end{array}$

$\mathrm{C}$, immunoreactive cell bodies; $\mathrm{F}$, immunoreactive fibers; + , low density ++ , moderate density; +++ , high density; - , no immunoreactive cell bodies or fibers. 

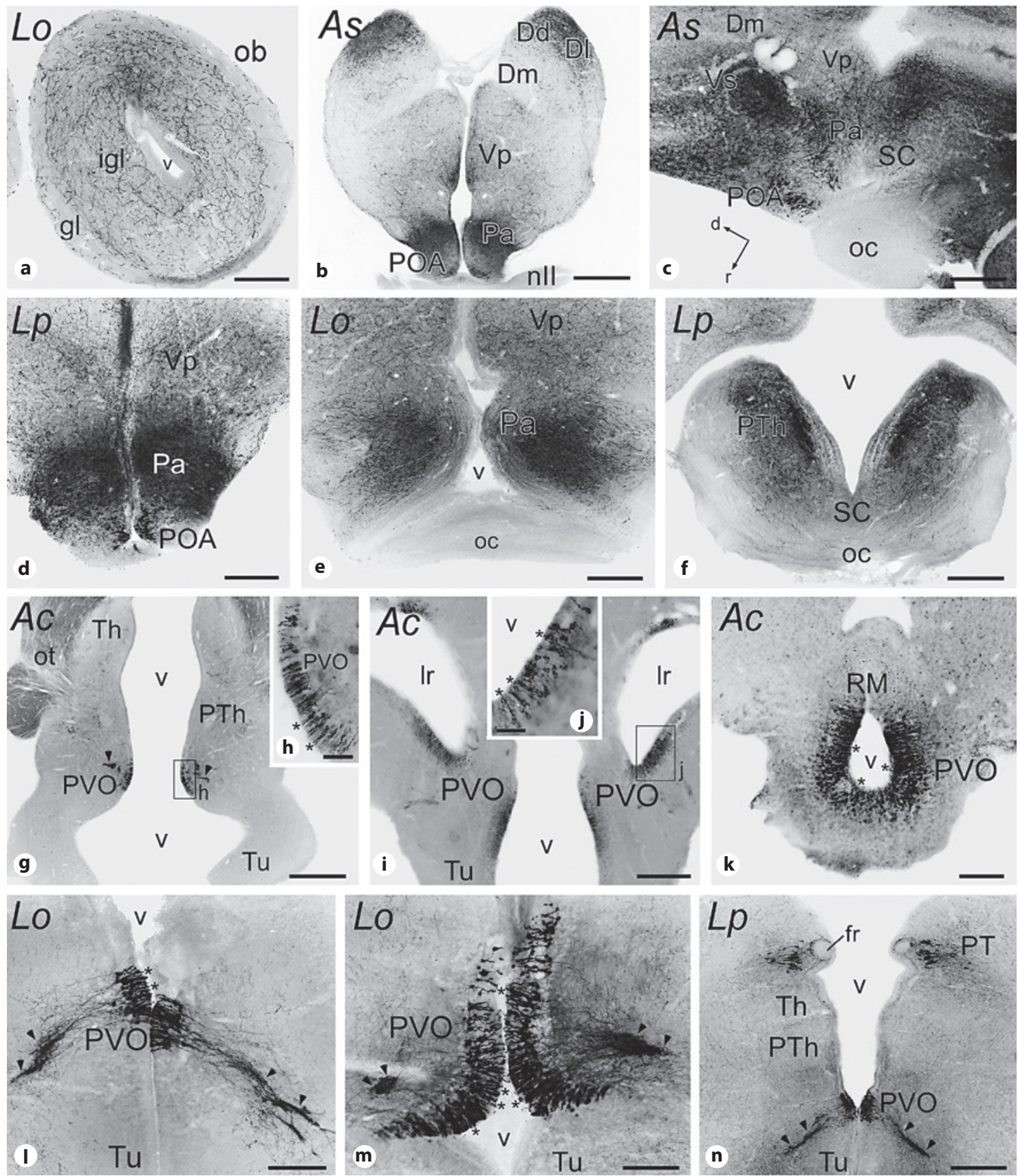

Fig. 3. Photomicrographs of transverse (a, b, d-n) and sagittal (c) sections through the forebrain of A. spatula (As), L. platyrhincus (Lp), L. oculatus (Lo), and A. calva (Ac; indicated in the upper left corner of each photomicrograph) illustrating 5-HT-ir cell bodies and fibers in the olfactory bulb (a), dorsal and ventral telencephalic areas (b), preoptic area (b-d), paraventricular hypothalamic region (b-e), suprachiasmatic nucleus (c, f), PVO ( $\mathbf{g}-\mathbf{n}$; the asterisks in $\mathbf{h}, \mathbf{j}, \mathbf{k}-\mathbf{m}$ indicate CSF-contacting cell processes; arrowheads in $\mathbf{g}$ and $\mathbf{I}-\mathbf{n}$ point to 5-HT-ir cell processes collected from the PVO), and the pretectal area (n). For abbreviations, see list. Scale bars, $500 \mu \mathrm{m}$ (g), $200 \mu \mathrm{m}(\mathbf{a}-\mathbf{f}, \mathbf{i}$, and $\mathbf{n}), 100 \mu \mathrm{m}(\mathbf{k}-\mathbf{m}), 50 \mu \mathrm{m}(\mathbf{h}, \mathbf{j})$. 

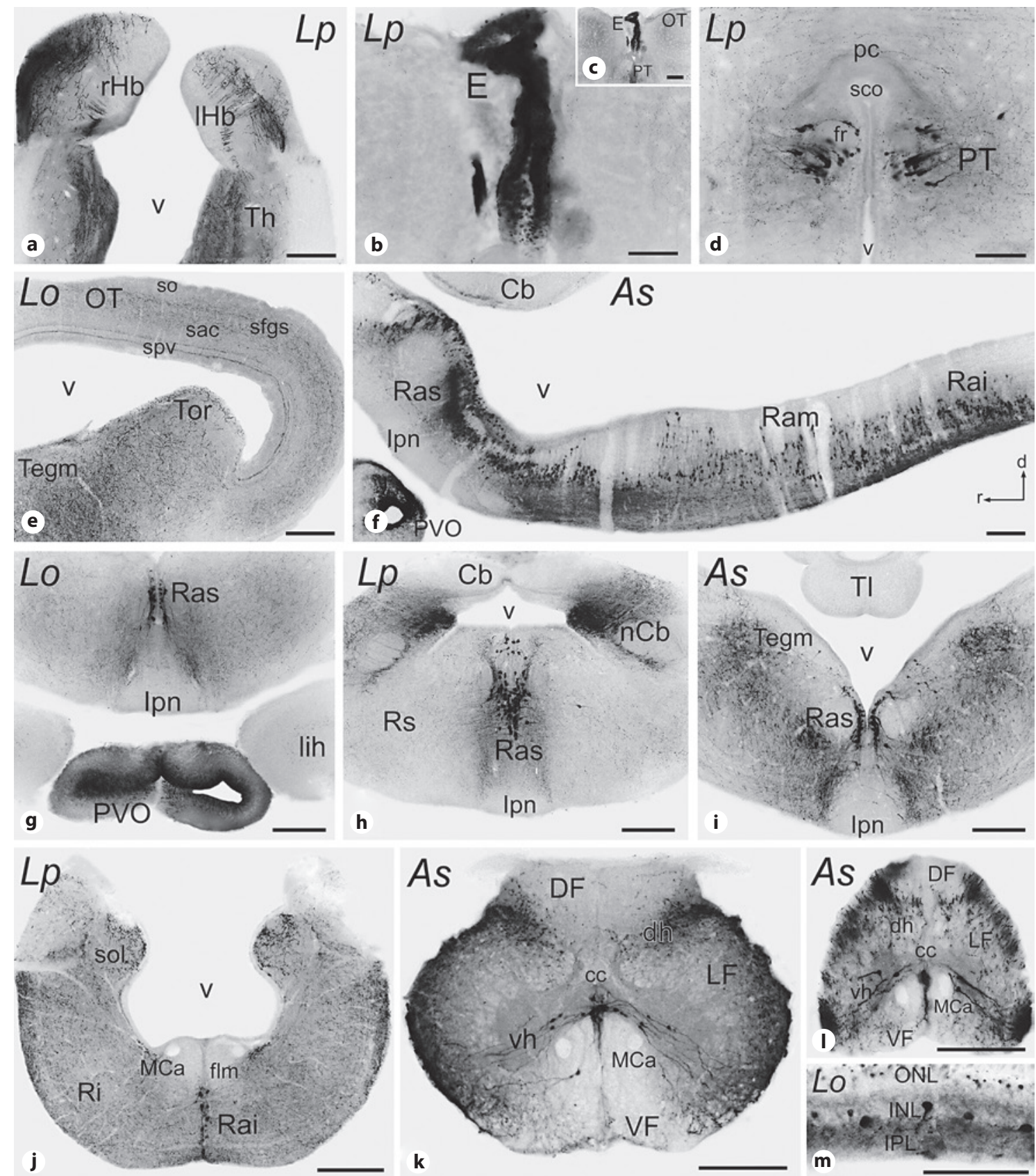

Fig. 4. Photomicrographs of transverse (a-e, $\mathbf{g}-\mathbf{m})$ and sagittal (f) sections through the diencephalon, brainstem, and spinal cord of A. spatula (As), L. platyrhincus $(L p)$, and L. oculatus (Lo; indicated in the upper corner of each photomicrograph) illustrating 5-HT-ir cell bodies and fibers in the thalamus and the asymmetric habenula (a), epiphysis (b, c), pretectum (d), optic tectum, torus semicircularis, and mesencephalic tegmentum (e), entire rhombencephalic raphe column $(\mathbf{f})$, superior raphe nucleus $(\mathbf{g - i})$, inferior raphe nucleus $(\mathbf{j})$, rostral and caudal levels of the spinal cord (k, I), and the retina (m). For abbreviations, see list. Scale bars, $500 \mu \mathrm{m}(\mathbf{c}), 200 \mu \mathrm{m}(\mathbf{a}$, e-I), $100 \mu \mathrm{m}$ (b, d, and $\mathbf{m})$. 

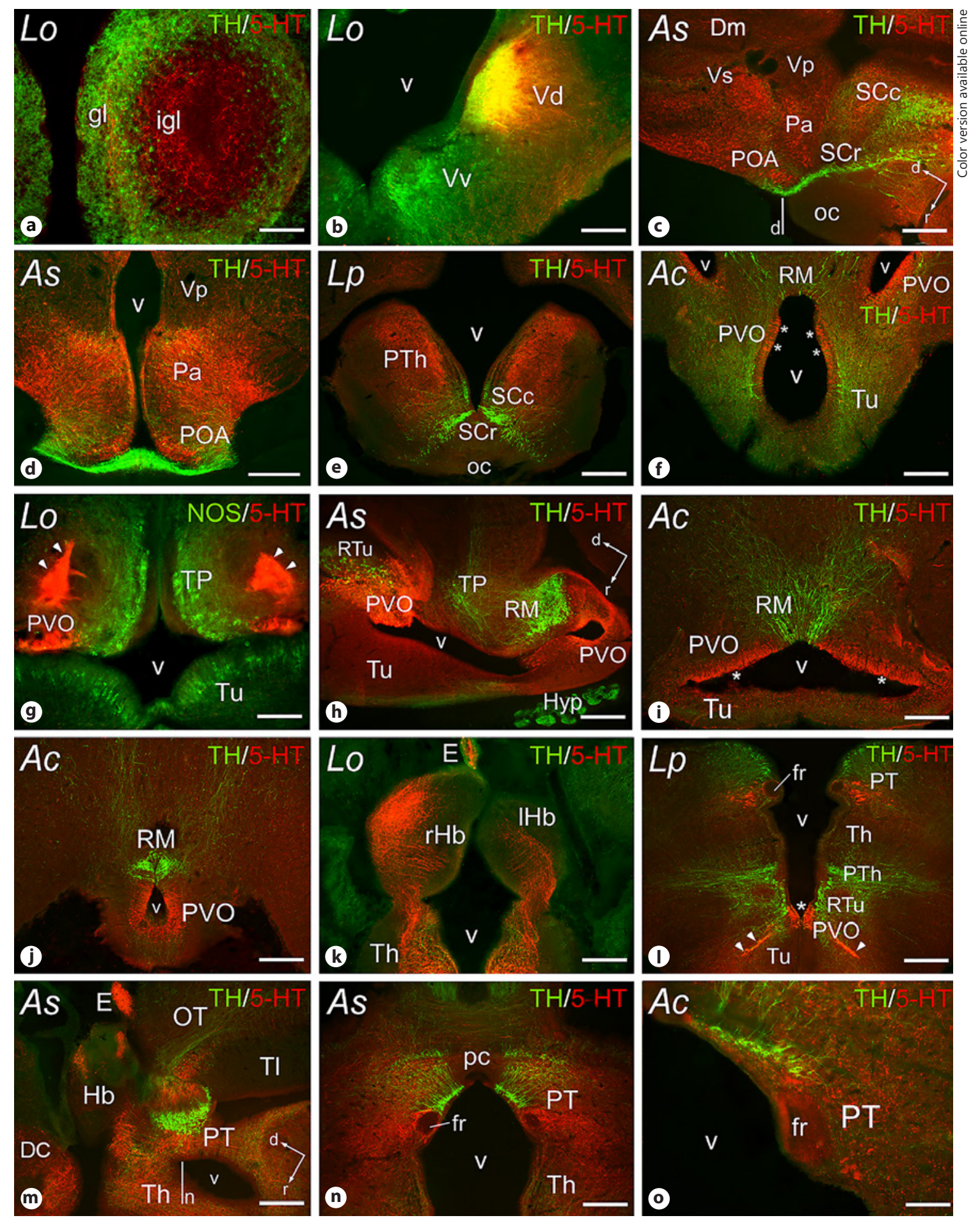

Fig. 5. Photomicrographs of transverse $(\mathbf{a}, \mathbf{b}, \mathbf{d}-\mathbf{g}, \mathbf{i}-\mathbf{I}, \mathbf{n}, \mathbf{0})$ and sagittal $(\mathbf{c}, \mathbf{h}, \mathbf{m})$ double labeled sections through the forebrain of A. spatula (As), L. platyrhincus (Lp), L. oculatus (Lo), and A. calva ( $A c$; indicated in the upper left corner of each photomicrograph), showing staining for 5-HT and TH or NOS, as indicated in the upper right corner of each photomicrograph. The relationship between the different immunoreactive elements is illustrated for the olfactory bulb (a), ventral telencephalic areas of subpallium (b), preoptic area and paraventricular hypothalamic region $(\mathbf{c}, \mathbf{d}$; $\mathbf{d}$ is a transverse section at the level indicated in c), suprachiasmatic nucleus (c, e), PVO ( $\mathbf{f}-\mathbf{j}$, I; the asterisks in $\mathbf{f}, \mathbf{i}$, and $\mathbf{I}$ indicate CSFcontacting cell processes; arrowheads in $\mathbf{g}$ and $\mathbf{I}$ point to 5 -HT-ir cell processes collected from the PVO), thalamus, the asymmetric habenula and the epiphysis $(\mathbf{k}, \mathbf{m})$, and the pretectal area $(\mathbf{I}-\mathbf{o} ; \mathbf{n}$ is a transverse section at the level indicated in $\mathbf{m})$. For abbreviations, see list. Scale bars, $200 \mu \mathrm{m}(\mathbf{c}-\mathbf{f}, \mathbf{h}-\mathbf{n}), 100 \mu \mathrm{m}(\mathbf{a}, \mathbf{b}, \mathbf{g}, \mathbf{0})$. 

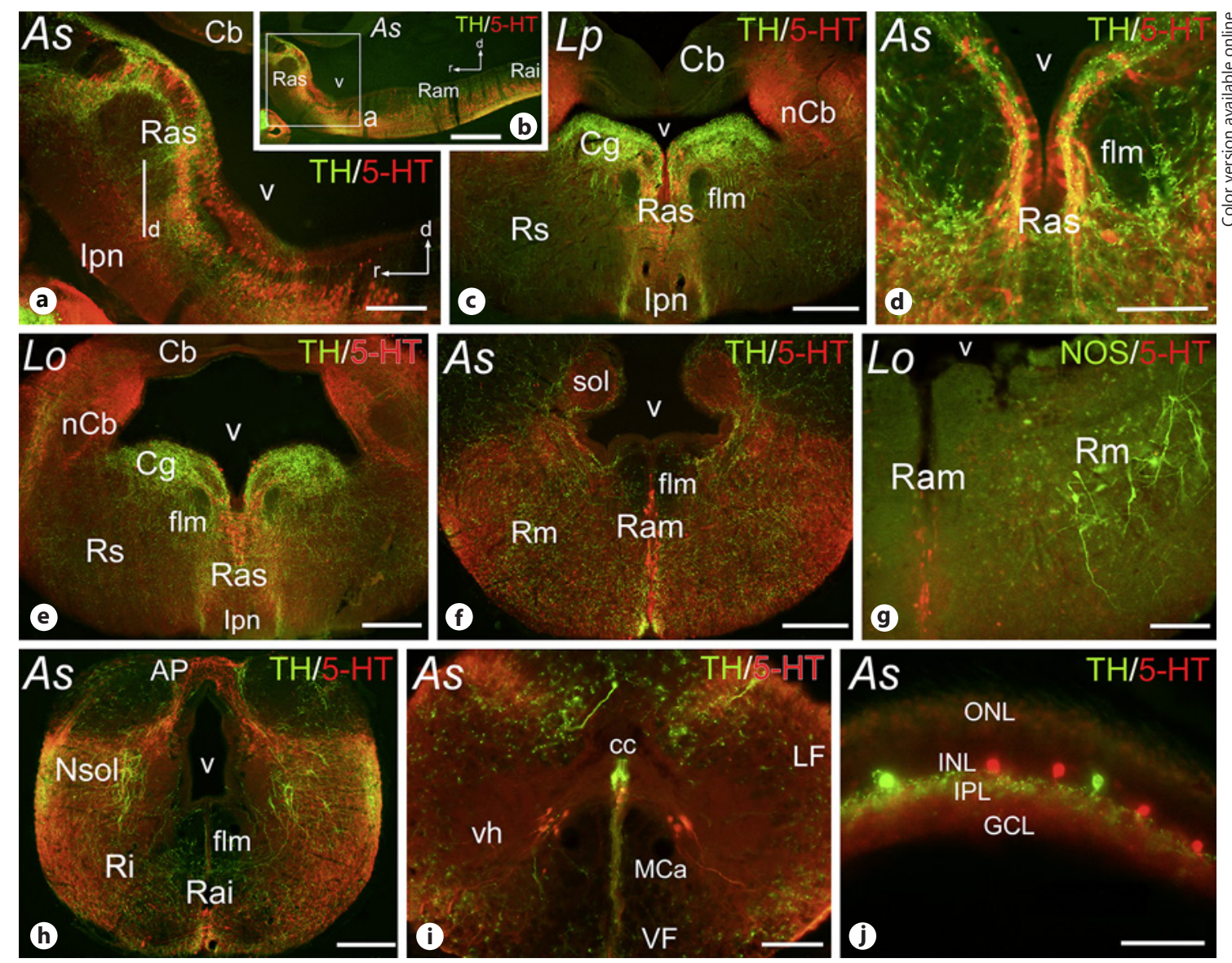

Fig. 6. Photomicrographs of transverse (c-j) and sagittal (a, b) double labeled sections through the rhombencephalon, spinal cord, and retina of A. spatula (As), L. platyrhincus ( $L p)$, and $L$. oculatus ( $L o$; indicated in the upper left corner of each photomicrograph), showing staining for 5-HT and TH or NOS, as indicated in the upper right corner of each photomicrograph. The re-

paminergic population in the preoptic area of holostean fishes (Fig. 2c, 3b-d, 5c, d) [Lozano et al., 2019].

The hypothalamus is located ventral to the telencephalon and rostral to the diencephalon, according to the prosomeric model, and is divided into the alar part that contains the paraventricular and subparaventricular regions and the basal part with the tuberal and mamillary regions (Fig. 1) [Puelles and Rubenstein, 2003, 2015]. In the alar part, numerous fibers and serotonergic terminals were observed in the paraventricular and subparaventricular regions, although within the latter the suprachiasmatic nucleus was barely innervated, especially in A. cal$v a$ (Fig. 2d, e, 3b-f, $5 c-e$ ). In turn, apart from a moderate 5-HT-ir innervation in all its subdivisions, which was generally scarcer in A. calva than in the Lepisosteiformes species, the basal portion of the hypothalamus harbored lationship between the different immunoreactive elements is illustrated for the superior raphe nucleus ( $\mathbf{a}-\mathbf{e}$; $\mathbf{d}$ is a transverse section at the level indicated in $\mathbf{a}$ ), median raphe nucleus $(\mathbf{f}, \mathbf{g})$, inferior raphe nucleus (h), spinal cord (i), and the retina (j). For abbreviations, see list. Scale bars, $500 \mu \mathrm{m}$ (b), $200 \mu \mathrm{m}(\mathbf{a}, \mathbf{c}, \mathbf{e}, \mathbf{f}, \mathbf{h}), 100 \mu \mathrm{m}$ $(\mathbf{d}, \mathbf{g}, \mathbf{i}), 50 \mu \mathrm{m}(\mathbf{j})$.

a prominent and highly immunoreactive population of serotonergic cells in the paraventricular organ (PVO; Fig. 2f-j). This large population of small cells with CSFcontacting processes (see asterisks in Fig. 3h, j-m, 5f, i, l) was present throughout the entire rostrocaudal extent of the periventricular layer of the basal hypothalamus, including the inferior hypothalamic lobes surrounding the lateral hypothalamic recesses, and was observed ventral to the retrotuberal and retromamillary dopaminergic cell populations (Fig. $3 g-j, 1, n$; 4 , g, $5 \mathrm{~h}-\mathrm{j}$ ). It is noteworthy that these cells showed conspicuous long processes that gathered in thick and highly immunoreactive fiber bundles ventrolaterally to the cells at rostral levels, dorsal to them at medium levels, and lateral to them at more caudal levels (see arrowheads in Fig. 3g, l-n, 5g, 1). In the retromamillary region and the infundibulum, the serotonergic 
innervation was more noticeable than in other hypothalamic areas (Fig. 3k, 4f, g, 5f, i, j), but the hypophysis lacked 5-HT-ir cells and fibers (Fig. 2h-j, 5h).

The diencephalon, the caudal forebrain region, is divided in the prosomeric model into 3 rostrocaudal prosomeres (p1-p3; Fig. 1), comprising in its alar parts the pretectum (p1), the thalamus and epithalamus (p2), and the prethalamus ( $\mathrm{p} 3)$, whereas the basal plate represents the tegmental regions (p1, p2) and the posterior tubercle (p3). Almost all diencephalic regions were richly innervated with serotonergic fibers and terminal-like structures (Fig. 2e-h, 3g, n, 5l), being more conspicuous at the rostral levels of the prethalamus and thalamus (Fig. 3f, 4a, $5 \mathrm{e}, \mathrm{k}, \mathrm{m}$ ). In addition, the asymmetric habenula housed highly immunoreactive serotonergic fibers, especially abundant in the lateroventral region of the right habenula of the Lepisosteiformes species (Fig. 4a, 5k, m). Dorsal to the habenula in the epithalamus stands the tubular epiphysis or pineal organ, where a high number of small and rounded 5-HT-ir cells were observed with an intense immunoreactivity (Fig. 2e, 4b, c, 5k, m). In contrast, the subcommissural organ located between the caudal end of the habenular commissure and the rostral end of the posterior commissure was devoid of 5-HT-ir elements (Fig. 4d). Another diencephalic 5-HT-ir cell population, apart from that observed in the epiphysis, was found in the pretectum (Fig. 2f, g, 3n, 4d). These pear-shaped cells with laterally directed processes were situated ventral to the prominent pretectal dopaminergic population [Lozano et al., 2019]. Along the pretectum, they accompany the fasciculus retroflexus, which appeared to be encircled by 5-HT-ir cells and fibers but itself lacked serotonergic labeling (Fig. 3n, 4d, 5l-o).

\section{Midbrain}

No 5-HT-ir cells were detected in the midbrain, but widespread serotonergic innervation was observed in almost all mesencephalic areas (Fig. 2f-l). In the alar midbrain, the optic tectum was the most profusely innervated region, especially the stratum fibrosum et griseum superficiale and, to a lesser extent, the stratum album centrale and the periventricular layer of the lateral part of the tectum, whereas the stratum opticum appeared almost devoid of labeling (Fig. 2g-k, 4e) [nomenclature after Meek and Nieuwenhuys, 1998]. Also, in the dorsal part of the mesencephalon, mainly in the Lepisosteiformes species, the torus semicircularis showed a moderate density of fibers and terminal-like structures, which was less conspicuous in the torus lateralis (Fig. $2 \mathrm{~h}-\mathrm{j}, 4 \mathrm{e}$ ). In contrast, the torus longitudinalis was devoid of 5-HT-ir elements
(Fig. $2 \mathrm{~g}-\mathrm{j}, 4 \mathrm{i}, 5 \mathrm{~m}$ ). In the basal midbrain, the mesencephalic tegmentum presented a moderate serotonergic innervation that was observed lateral to the oculomotor nucleus at rostral levels (Fig. $2 \mathrm{~h}-\mathrm{j}, 4 \mathrm{e}, \mathrm{i}$ ).

\section{Hindbrain}

The rhombencephalon, divided rostrocaudally into rhombomeres ( $\mathrm{r} 0-\mathrm{r} 8)$ that can be inferred based on the localization of the cranial nerve motor nuclei [Morona et al., 2013], housed in its large basal region numerous 5 -HT-ir cells in the raphe nuclei. This prominent group of serotonergic cells was observed as a long and continuous column in the midline of the rhombencephalon, from rostral levels of the isthmus ( $\mathrm{r} 0$ ) to caudal rhombencephalic levels ( $(\mathrm{r} 8)$, even entering the rostral spinal cord (Fig. 1, 2j-q, 4f, 6b). In the raphe column, 3 different rostrocaudal subdivisions have been classically considered [after Meek and Nieuwenhuys, 1998], they are the superior (Ras; from $\mathrm{r} 0$ to $\mathrm{r} 3$ ), median (Ram; from $\mathrm{r} 4$ to $\mathrm{r} 6$ ), and inferior (Rai; $r 7$ and r8) nuclei, among which we observed some differences in the density and location of serotonergic cells. The Ras showed the largest population of 5-HTir cells. It was organized in 2 dorsoventrally oriented cell clusters in the midline, ventromedial to the trochlear nucleus at the most rostral levels of Ras, and to the central gray more caudally, remaining dorsal to the interpeduncular nucleus and neuropile, which lacked serotonin labeling (Fig. 2j-m, 4g-i, 6a, c, e). Most of these cells had a main dendritic trunk that arborized ventrally and ventrolaterally, and appeared profusely innervated with $\mathrm{TH}$-ir fibers and terminal-like structures (Fig. 6a, c-e). The bilateral group of the Ras merged caudally into a single group in the midline that extended as far as the caudal levels of the trigeminal motor nucleus (Fig. $2 \mathrm{~m}, 4 \mathrm{~h}, 6 \mathrm{e}$ ). At the same levels of Ras, the central gray and the laterodorsal tegmental nucleus showed a slight serotonergic innervation, but no immunoreactive serotonergic cells were observed laterally in the reticular formation (Fig. $2 \mathrm{k}-$ $\mathrm{m}, 4 \mathrm{~h}, 6 \mathrm{c}, \mathrm{e})$.

In the dorsal part of rhombomere 1, the cerebellum of holostean fishes showed serotonergic fibers scattered throughout the cerebellar auricle and the granular layer of the corpus, with some fibers crossing at the cerebellar commissure, whereas a high concentration of 5-HT-ir fibers and terminal-like structures was observed in the cerebellar nucleus (Fig. 2k-n, 4h, 6c, e).

The median portion of the raphe column, from $\mathrm{r} 4$ levels to the facial motor nucleus in $\mathrm{r} 6$, formed a single vertical band of small serotonergic cells that was located away from the ventricle, in a more ventral position than the 5-HT-ir
36

Brain Behav Evol 2020;95:25-44 DOI: $10.1159 / 000505473$
Lozano/González/López 
Table 2. Summary of the distribution of 5-HT-ir cells in different areas of the CNS of the main groups of vertebrates studied

\begin{tabular}{|c|c|c|c|c|c|c|c|c|c|c|c|}
\hline & Agnathans & Chondrichthyans & Cladistians & Chondrosteans & Holosteans & Teleosts & Lungfishes & Amphibians & Reptiles & Birds & Mammals \\
\hline \multicolumn{12}{|l|}{ Forebrain } \\
\hline Olfactory bulb & $+/-$ & - & - & + & - & $+/-$ & - & - & - & - & - \\
\hline Subpallium & - & - & - & + & - & - & - & - & - & - & - \\
\hline Preoptic area & + & + & + & + & + & $+1-$ & + & $+/-$ & - & - & - \\
\hline Basal hypothalamus & + & + & + & + & + & + & + & + & $+1-$ & + & $+/-$ \\
\hline \multicolumn{12}{|l|}{ Brainstem } \\
\hline \multicolumn{12}{|l|}{ Optic tectum/ } \\
\hline \multicolumn{12}{|l|}{$\begin{array}{l}\text { superior colliculus } \\
\text { Torus semicircularis/ }\end{array}$} \\
\hline inferior colliculus & - & - & - & - & - & $+1-$ & - & - & - & - & - \\
\hline Raphe nuclei & + & + & + & + & + & + & + & + & + & + & + \\
\hline
\end{tabular}

+, presence of 5-HT-ir cells; -, absence of 5-HT-ir cells; +/-, presence of 5-HT-ir cells in some species of the group; ?, no data available.

References: agnathans: Pierre et al., 1992; Antri et al., 2006; Abalo et al., 2007, 2008; Barreiro-Iglesias et al., 2008; Cornide-Petronio et al., 2013; chondrichthyes: Ritchie et al., 1983, 1984; Stuesse et al., 1990, 1991a, b, 1995; Stuesse and Cruce, 1991, 1992; Schuette and Chappell, 1998; Carrera et al., 2008; cladistians: López and González, 2014; chondrosteans: Adrio et al., 1999; Piñuela and Nortchutt, 2007; holosteans: Parent and Northcutt, 1982; Chiba and Oka, 1999; present results; teleosts: Kah and Chambolle, 1983; Ekström and Van Veen, 1984; Frankenhuis-van den Heuvel and Nieuwenhuys, 1984; Meek and Joosten, 1989; Johnston et al., 1990; Corio et al., 1991; Bolliet and Ali, 1992; Batten et al., 1993; Khan and Thomas, 1993; Negishi and Wagner, 1995; Rodríguez-Gómez et al., 2000; Kaslin and Panula, 2001; Rink and Guo, 2004; Maurer et al., 2010; lungfishes: López and González, 2015; amphibians: Ueda et al., 1984; van Mier et al., 1986; Corio et al., 1992; Zhu et al., 1992; Clairambault et al., 1994; Schütte, 1994; Dicke et al., 1997; Beltramo et al., 1998; Branchereau et al., 2000; reptiles: Ueda et al., 1983; Smeets and Steinbusch, 1988; Bennis et al., 1990; Challet et al., 1991; Kiehn et al., 1992; Kawano et al., 2006; Rodrigues et al., 2008; birds: Ikeda and Goto, 1971; Sano et al., 1983; Sako et al., 1986a, b; Cozzi et al., 1991; Challet et al., 1996; Ríos et al., 1997; Meneghelli et al., 2009; mammals: Dahlström and Fuxe, 1964; Jacobowitz and MacLean, 1978; Schofield and Everitt, 1981; Steinbusch, 1981; Törk, 1990; Baker et al., 1991a, b; Botchkina and Morin, 1993; Bjarkam et al., 1997; Manger et al., 2002; Maseko et al., 2007.

cells of Ras (Fig. 2n, o, 4f, 6f), and the number of labeled cells decreased with respect to that of Ras (Fig. 4f). Lateral to the raphe cell column, the reticular formation showed a moderate number of serotonergic fibers and terminals that increased following a rostrocaudal gradient (Fig. 2l-q, 4h, j, $6 c, e, f, h)$. Many of these fibers were seen around the nitrergic cells of the reticular formation (Fig. $6 \mathrm{~g}$ ). In turn, dorsally in the octavolateral area only a fairly low serotonergic innervation was observed (Fig. $2 \mathrm{~m}, \mathrm{n}$ ), and the fasciculus longitudinalis medialis, as well as the Mauthner cell axon, lacked immunoreactivity (Fig. 4j-1, 6c-f, h, i).

In the caudal pole of the raphe column, from the glossopharyngeal motor nucleus to the spinal cord, the small serotonergic cells of Rai were located in the midline, more ventrally than the cells of Ram (Fig. 2p, q, 4f, j). They also constituted a vertical band of cells, although at the level of the obex they appeared to be stacked in the most ventral part (Fig. 6h). At the same levels as the Rai, we observed a moderate 5-HT-ir innervation in the solitary tract and around the catecholaminergic cells of the nucle- us of the solitary tract (Fig. $20-q, 4 j, 6 h$ ), while the area postrema, especially in Lepisosteiformes species, housed a high density of immunoreactive fibers intermingled with the small catecholaminergic cells located in this region (Fig. 6h).

\section{Spinal Cord}

The spinal cord of holostean fishes showed 2 populations of serotonergic cells (Fig. 2r). One population was situated ventral to the central canal and was formed by small cells with CSF-contacting processes. These cells lie just ventral to the dopaminergic cells in this region described recently in holosteans [Lozano et al., 2019] (Fig. 4k, 6i). The other population was visible in the ventral horn and consisted of small bipolar cells with long processes directed ventrolaterally (Fig. $4 \mathrm{k}, 6 \mathrm{i}$ ). In addition, some displaced cells were occasionally observed ventral to the Mauthner cell axon (Fig. 4k). Both populations constituted continuous columns throughout the rostrocaudal extent of the spinal cord (Fig. 4l). Together 
with the 5-HT-ir cell populations, a remarkable serotonergic innervation was observed, mostly concentrated in the lateral and ventrolateral funiculi, but also present in the dorsal horn and, to a lesser extent, in the ventral funiculus (Fig. 2r, 4k).

\section{Retina}

The inner nuclear layer of the retina (INL) of holostean fishes harbored a population of serotonergic amacrine cells that sent processes into the inner plexiform layer, where a low serotonergic innervation was detected (Fig. $4 \mathrm{~m}$ ). These cells appeared intermingled with the dopaminergic neurons present in the inner nuclear layer, but no doubly labeled cells were observed, therefore they constituted 2 different populations of amacrine cells (Fig. 6j).

\section{Discussion}

The present study is the first comprehensive neuroanatomical analysis of the serotonergic system in holostean fishes, including representative species of the 3 extant genera of the group. The only available information on the serotonergic system in this group had either been obtained by classical histochemical methods [Parent and Northcutt, 1982], was fragmentary [Onstott and Elde, 1986; Chiba, 2007; Wai et al., 2007], or corresponded only to 1 species (L. oculatus, previously identified as $L$. productus) [Chiba and Oka, 1999]. One of the main features of this system is its neuroanatomical conservation in vertebrate phylogeny [Parent, 1984], confirmed by the numerous studies conducted on representative species of most groups of vertebrates (see citations in Introduction). With our study, we intend to complete the knowledge of the evolution of the serotonergic system, in particular in actinopterygian fishes.

\section{Comparative Aspects of the Regional Distribution of} Serotonergic Cells and Fibers

The general organization and variations of the 5-HT-ir cells and fibers in holostean fishes are discussed below, in addition to specific comparisons with other groups of fishes and, when needed, with other classes of vertebrates to assess common and particular features of this neurotransmission system in holosteans (Table 2).

\section{Forebrain}

In the 4 species of holostean fishes studied, no 5-HT-ir cells were observed in the olfactory bulbs or the pallial and subpallial telencephalic areas. The lack of labeled cells in these areas is a common feature in vertebrates, with the exceptions of the olfactory bulbs of the sea lamprey, a marine teleost [Khan and Thomas, 1993; Abalo et al., 2007], and chondrostean fishes that also house a serotonergic population in the ventral part of the ventral telencephalic area [Adrio et al., 1999; Piñuela and Northcutt, 2007]. However, these telencephalic areas showed a remarkable 5-HT-ir innervation, which is also a conserved characteristic observed in all vertebrates.

The only serotonergic population present in the telencephalon of holosteans lies in the preoptic area, which constitutes a subpallial region of the telencephalon according to the prosomeric model [Puelles and Rubenstein, 2003]. All groups of fishes, that is, agnathans, chondrichthyans, cladistians, chondrosteans, the majority of teleosts, and lungfishes, show this preoptic population [Lillesaar, 2011; López and González, 2014, 2015], which can also be observed in amphibians, with the exception of urodeles [Ueda et al., 1984; Corio et al., 1992; Clairambault, 1994; Dicke et al., 1997; Beltramo et al., 1998]. In contrast, amniotes lack a preoptic serotonergic group, which is why it is defined as a general characteristic of anamniotes, with the exception of some teleosts and urodeles that may have lost it independently.

The population of serotonergic cells in the hypothalamic PVO proved to be the most prominent in the forebrain of holostean fishes. This group of CSF-contacting cells had already been reported in L. oculatus [Chiba and Oka, 1999], and is a highly conserved serotonergic group observed in all anamniotes [Clairambault et al., 1994; Dicke et al., 1997; Adrio et al., 1999; Abalo et al., 2007; Piñuela and Northcutt, 2007; Carrera et al., 2008; Lillesaar, 2011; López and González, 2014, 2015]. However, it has been named differently in previous works. For example, in teleosts, some authors refer to the PVO divided into anterior, intermediate, and posterior parts [Kaslin and Panula, 2001], whereas other researchers have called these regions the periventricular organ, intermediate nucleus, and caudal periventricular hypothalamus [Rink and Wullimann, 2001]. Most reptile species studied have this serotonergic cell population, although there are exceptions, such as the chameleon, without 5-HT-ir cells in PVO [Bennis et al., 1990], or the Nile crocodile, with cells in the periventricular organ but not in the ependymal wall of the infundibular recess [Rodrigues et al., 2008]. In turn, all the avian species studied posses 5-HT-ir cells in the PVO [Sano et al., 1983; Cozzi et al., 1991; Challet et al., 1996], while among mammals only monotremes have this serotonergic population [Manger et al., 2002]. Therefore, the presence of serotonergic cells in the PVO is a primitive
38

Brain Behav Evol 2020;95:25-44 DOI: 10.1159/000505473
Lozano/González/López 
feature lost in some reptile species and most mammals. Recently, we have observed the presence of dopamine immunoreactive cells in the PVO of Lepisosteus [Lozano et al., 2019] with a morphology similar to the 5-HT-ir cells described here, and this situation has also been reported in cladistians and lungfishes [López and González, 2017; López et al., 2019]. Dopamine and 5-HT might be co-expressed in PVO cells, as demonstrated in teleosts, amphibians, and birds, which would support the idea that this characteristic was already present in the common ancestor of the Osteichthyes [Xavier et al., 2017; Yamamoto et al., 2017]. The precise function of the PVO 5-HT-ir cells remains unknown, but, due to their cell processes that contact the CSF, it was suggested that their nature is chemosensory and that they may also be involved in the control of hypophysial functions [Lillesaar, 2011]. In addition, 5-HT synthetized by these neurons has been shown to promote adult neurogenesis by inducing the radial glia progenitors to proliferate in periventricular hypothalamic regions of zebrafish [Pérez et al., 2013].

The population of 5-HT-ir cells densely packed in the epiphysis of holosteans, housed in the dorsal epithalamus, is one of the most conserved features in the evolution of the CNS, being present in all vertebrate groups (Table 2), although it was not detected initially in Lepisosteus [Chiba and Oka, 1999]. Serotonin synthesized by these neurons is the precursor of melatonin, essential in the regulation of circadian rhythm, as observed in lamprey [Tamotsu et al., 1997], zebrafish [Lillesaar, 2011], or rat. The population of pinealocytes in the latter is subdivided into $\beta$-pinealocytes, which release $\mathrm{N}$-acetyl-serotonin (the molecule between serotonin and melatonin in its synthetic pathway), and $\alpha$-pinealocytes, which are specialized in the synthesis of melatonin [Mays et al., 2018].

Following the terminology established to define 3 different zones in the pretectal region of tetrapods and lungfishes (precommissural, juxtacommissural, and commissural zones) [Morona et al., 2011; López and González, 2015], holostean fishes possess serotonergic cells in the precommissural zone of the pretectum, separated from the dopaminergic pretectal group in the commissural zone [Lozano et al., 2019]. This pretectal group, which was previously considered thalamic in L. oculatus [Chiba and Oka, 1999], has been reported in all fish groups [Lillesaar, 2011; López and González, 2014, 2015], with the exception of the white sturgeon [Piñuela and Northcutt, 2007] and the teleost Solea senegalensis [RodríguezGómez et al., 2000]. In contrast, tetrapods do not possess this pretectal serotonergic population, with the notable exception of the Nile crocodile [Rodrigues et al., 2008].
These 5-HT-ir neurons are probably involved in the control of visuomotor behavior and the integration of different visual inputs [Wullimann, 1998].

\section{Brainstem}

The mesencephalon of holostean fishes is widely innervated by serotonergic fibers, especially the optic tectum, but - like in almost all vertebrate groups - it lacks 5-HT-ir cells. Some exceptions have been reported in the lamprey Lampetra fluviatilis and the lungfishes that possess immunoreactive cells in the optic tectum [Pierre et al., 1992; López and González, 2015], some teleosts that have cells in the torus semicircularis [Bonn and König, 1990; Khan and Thomas, 1993], and chondrichthyans that show serotonergic cells in the mesencephalic tegmentum [Stuesse et al., 1990, 1991a, b; Stuesse and Cruce, 1991, 1992]. However, the conspicuous serotonergic innervation of the optic tectum is a conserved feature in all vertebrates. In holosteans, the superficial layers are almost devoid of fibers, while the deeper layers house the majority of them, in line with observations reported in other groups of fishes such as cladistians [López and González, 2014], teleosts [Meek and Joosten, 1989; Batten et al., 1993; Khan and Thomas, 1993; Rodríguez-Gómez et al., 2000; Kaslin and Panula, 2001], and lungfishes [López and González, 2015]. It should be noted that this innervation in fishes originates mainly in the pretectal cell population [Johnston et al., 1990; Rodríguez-Gómez et al., 2000; Kaslin and Panula, 2001; Lillesaar et al., 2009], while in tetrapods, specifically in mammals, the raphe nuclei are the source of the fibers that reach the superior colliculus [May, 2006].

The raphe nuclei in the rhombencephalon contain the largest serotonergic population in the brain of holostean fishes. This long and continuous column can be subdivided into the superior, median, and inferior parts according to the morphology of its cells, their position and the extent across rhombomeres, taking as reference the cranial nerve motor nuclei (Fig. 1) [Morona et al., 2013]. In an earlier immunohistochemical study, only the most caudal part of the raphe was detected [Chiba and Oka, 1999], although by histochemical methods it was previously described as a continuous column spanning all the rostrocaudal extension of the rhombencephalon [Parent and Northcutt, 1982], and this situation has been confirmed immunohistochemically in this study in all species of holostean fishes studied. The superior raphe nucleus, from levels of the trochlear nucleus ( $\mathrm{r} 0$ ) to the Mauthner cell bodies, is the most conspicuous of the raphe nuclei. The cells located at the rostral pole of the nucleus may correspond to those described in some studies in fishes as 
belonging to the interpeduncular nucleus [Stuesse et al., 1990, 1991a, b; Stuesse and Cruce, 1991; Rodríguez-Gómez et al., 2000]. At levels of $r 4$, there is not a disruption in the column, but a reduction in the number of cells that are located more ventrally, which led us to name this part as the median raphe nucleus, while at levels of $r 7$ the serotonergic cells occupied a position even more ventral, and for this reason this part was named the inferior raphe nucleus, which extends to the obex, where the cells are stacked in the most ventral part of the basal hindbrain.

The raphe column is probably the most conserved serotonergic structure throughout vertebrate evolution [Moret et al., 2004; Alonso et al., 2013]. However, some differences in the organization of the nuclei have been observed. Specifically, more than 20 subgroups were observed in lamprey (later rearranged to a less fragmentary vision of the raphe) [Pierre et al., 1992; Antri et al., 2006], 4 main groups in zebrafish [Ekström and Van Veen, 1984; Ekström et al., 1985; Ekström, 1994; Kaslin and Panula, 2001], and some displaced serotonergic cells in the reticular formation of chondrichthyans [Stuesse et al., 1995; Carrera et al., 2008], chondrosteans [Adrio et al., 1999], some teleosts [Meek and Joosten, 1989; Batten et al., 1993; Rodríguez-Gómez et al., 2000], the anuran Rana pipiens [Adli et al., 1999], and some amniotes [Lidov and Molliver, 1982; Yamada et al., 1984; Wolters et al., 1985; Aitken and Törk, 1988; Cozzi et al., 1991; Challet et al., 1996; Rodrigues et al., 2008]. It has been demonstrated that the different subsystems in the raphe nuclei of teleosts and mammals possess unique genetic programming and functions [Gaspar and Lillesaar, 2012], a condition that may be similar in holostean fishes, but further research is needed to confirm it. Thus, the superior raphe nucleus would project its axons to the forebrain, while the inferior raphe nucleus would project locally to the hindbrain and to the spinal cord, as occurs in other groups of fishes and amphibians [Ritchie et al., 1984; Ronan and Northcutt, 1985; Tan and Miletic, 1990; Lillesaar, 2011].

\section{Spinal Cord}

The presence of serotonergic cells in the spinal cord is a feature preserved in all fish groups and becomes a variable characteristic in amphibians, reptiles, and birds, whereas the spinal cord of mammals does not possess any serotonergic cells [Sako et al., 1986b; Kiehn et al., 1992; Branchereau et al., 2000; Lillesaar, 2011; López and González, 2014, 2015]. It seems that the 5-HT-ir innervation present in the spinal cord has its source in the cells of this region, as has been observed in other groups of fishes [Wallén et al., 1989; Stuesse and Cruce, 1991; Adrio et al., 1999; Chiba and Oka, 1999; Brustein et al., 2003b;
Barreiro-Iglesias et al., 2008; Carrera et al., 2008; Gabriel et al., 2009; Lillesaar, 2011], together with the descending serotonergic fibers that arise in the inferior raphe nucleus, as demonstrated in chondrichthyans, teleosts, lungfishes, and amphibians [Ritchie et al., 1984; Ronan and Northcutt, 1985; Tan and Miletic, 1990]. This innervation could be involved in the modulation of locomotion at spinal levels, as it occurs in lampreys and zebrafish [Wallén et al., 1989; Brustein et al., 2003a; Gabriel et al., 2009].

\section{Retina}

The serotonergic population of amacrine cells observed in the inner nuclear layer of the retina of holosteans is one of the most conserved features in evolution [Wilhelm et al., 1993; Lillesaar, 2011; López and González, $2014,2015]$. No labeled bipolar, displaced amacrine, or ganglion cells have been identified in this study in holostean fishes, as in cladistian fishes [López and González, 2014], but serotonergic bipolar cells have been described in some chondrichthyans and amphibians [Schütte, 1994; Schuette and Chappell, 1998; Dünker, 1999], displaced amacrine cells in lungfishes [López and González, 2015], and ganglion cells in amphibians [Li et al., 1990; Liu and Debski, 1993; Huang and Moody, 1997]. Initially, it was thought that the serotonergic retinal cells lacked the ability to synthesize serotonin and they would accumulate it from an extrinsic source [Osborne and Barnett, 1990; Wilhelm et al., 1993; Schütte, 1994], but it has been demonstrated that the retinal cells of lamprey and zebrafish possess the enzyme tryptophan hydroxylase and, therefore, intrinsic ability to synthesize serotonin [Bellipanni et al., 2002; Cornide-Petronio et al., 2013].

\section{Conclusions}

The present study provides a detailed and complete map of the serotonergic structures in the CNS of holostean fishes, demonstrating some previously unidentified 5-HT-ir cell populations in the preoptic area, the epiphysis, the pretectum, and the retina. The comparative analysis of the serotonergic structures in holosteans and other vertebrates highlights conserved features in all fish groups, such as the populations in the preoptic area, the PVO, the pretectum, and the spinal cord. In addition, most of these characteristics are also present in amphibians. Other traits preserved in all groups of vertebrates include the populations in the epiphysis, the raphe nuclei, and the retina. Therefore, the presence of serotonin in the CNS has followed a progressive reduction throughout the evolution of vertebrates, specifi- 
cally in amniotes, among which non-monotreme mammals only conserve the serotonergic populations of the epiphysis, the raphe column, and the retina.

\section{Acknowledgements}

This work was supported by a Spanish MICINN grant, grant/ award No. BFU2015-66041P (with European FEDER support).

\section{Statement of Ethics}

The original research reported herein was performed according to the regulations and laws established by European Union (2010/63/EU) and Spain (Royal Decree 53/2013) for care and handling of animals in research and after approval from the Complutense University to conduct the experiments described.

\section{Disclosure Statement}

The authors declare that they have no conflicts of interest. No financial conflict of interest was identified, and the terms of the funding arrangement were reviewed and approved by the Complutense University of Madrid in accordance with its policy on objectivity in research.

\section{Author Contributions}

The 3 authors had full access to all the data in the study and take responsibility for the integrity of the data and the accuracy of the data analysis. The study was devised by the group of researchers; D.L. and J.M.L. led the experimental part and A.G. the figure preparation. D.L. and J.M.L. wrote the majority of the article, further supplemented by A.G. The final edition was created by A.G. and J.M.L. and all authors approved the article.

\section{References}

Abalo XM, Villar-Cerviño V, Villar-Cheda B, Anadón R, Rodicio MC. Neurochemical differentiation of horizontal and amacrine cells during transformation of the sea lamprey retina. J Chem Neuroanat. 2008 Mar;35(2):22532.

Abalo XM, Villar-Cheda B, Meléndez-Ferro M, Pérez-Costas E, Anadón R, Rodicio MC. Development of the serotonergic system in the central nervous system of the sea lamprey. J Chem Neuroanat. 2007 Sep;34(1-2):29-46.

Adams JC. Heavy metal intensification of DABbased HRP reaction product. J Histochem Cytochem. 1981 Jun;29(6):775.

Adli DS, Stuesse SL, Cruce WL. Immunohistochemistry and spinal projections of the reticular formation in the northern leopard frog, Rana pipiens. J Comp Neurol. 1999 Feb; 404(3):387-407.

Adrio F, Anadón R, Rodríguez-Moldes I. Distribution of serotonin (5HT)-immunoreactive structures in the central nervous system of two chondrostean species (Acipenser baeri and Huso huso). J Comp Neurol. 1999 May; 407(3):333-48.

Aitken AR, Törk I. Early development of serotonin-containing neurons and pathways as seen in wholemount preparations of the fetal rat brain. J Comp Neurol. 1988 Aug;274(1): $32-47$.

Alonso A, Merchán P, Sandoval JE, Sánchez-Arrones L, García-Cazorla A, Artuch R, et al. Development of the serotonergic cells in murine raphe nuclei and their relations with rhombomeric domains. Brain Struct Funct. 2013 Sep;218(5):1229-77.

Antri M, Cyr A, Auclair F, Dubuc R. Ontogeny of 5-HT neurons in the brainstem of the lamprey, Petromyzon marinus. J Comp Neurol. 2006 Apr;495(6):788-800.

Aroca P, Puelles L. Postulated boundaries and dif- ferential fate in the developing rostral hindbrain. Brain Res Brain Res Rev. 2005 Sep; 49(2):179-90.

Baker BI, Bird DJ. Neuronal organization of the melanin-concentrating hormone system in primitive actinopterygians: evolutionary changes leading to teleosts. J Comp Neurol. 2002 Jan;442(2):99-114.

Baker KG, Halliday GM, Halasz P, Hornung JP, Geffen LB, Cotton RG, et al. Cytoarchitecture of serotonin-synthesizing neurons in the pontine tegmentum of the human brain. Synapse. 1991a Apr;7(4):301-20.

Baker KG, Halliday GM, Hornung JP, Geffen LB, Cotton RG, Törk I. Distribution, morphology and number of monoamine-synthesizing and substance P-containing neurons in the human dorsal raphe nucleus. Neuroscience. 1991b;42(3):757-75.

Barreiro-Iglesias A, Villar-Cerviño V, Anadón R, Rodicio MC. Development and organization of the descending serotonergic brainstemspinal projections in the sea lamprey. J Chem Neuroanat. 2008 Oct;36(2):77-84.

Batten TF, Berry PA, Maqbool A, Moons L, Vandesande F. Immunolocalization of catecholamine enzymes, serotonin, dopamine and L-dopa in the brain of Dicentrarchus labrax (Teleostei). Brain Res Bull. 1993;31(3-4):233-52.

Bellipanni G, Rink E, Bally-Cuif L. Cloning of two tryptophan hydroxylase genes expressed in the diencephalon of the developing zebrafish brain. Gene Expr Patterns. 2002 Dec;2(3-4):251-6.

Beltramo M, Pairault C, Krieger M, Thibault J, Tillet Y, Clairambault P. Immunolocalization of aromatic L-amino acid decarboxylase, tyrosine hydroxylase, dopamine, and serotonin in the forebrain of Ambystoma mexicanum. J Comp Neurol. 1998 Feb;391(2):227-47.

Bennis M, Gamrani H, Geffard M, Calas A, Kah $\mathrm{O}$. The distribution of 5-HT immunoreactive systems in the brain of a saurian, the chameleon. J Hirnforsch. 1990;31(5):563-74.

Betancur-R R, Wiley EO, Arratia G, Acero A, Bailly N, Miya M, et al. Phylogenetic classification of bony fishes. BMC Evol Biol. 2017 Jul;17(1):162.

Bjarkam CR, Sørensen JC, Geneser FA. Distribution and morphology of serotonin-immunoreactive neurons in the brainstem of the New Zealand white rabbit. J Comp Neurol. 1997 Apr;380(4):507-19.

Bolliet V, Ali MA. Immunohistochemical study of the development of serotoninergic neurons in the brain of the brook trout Salvelinus fontinalis. Brain Behav Evol. 1992;40(5):234-49.

Bonn U, König B. Serotonin-immunoreactive neurons in the brain of Eigenmannia lineata (Gymnotiformes, Teleostei). J Hirnforsch. 1990;31(3):297-306.

Botchkina GI, Morin LP. Development of the hamster serotoninergic system: cell groups and diencephalic projections. J Comp Neurol. 1993 Dec;338(3):405-31.

Branchereau P, Rodríguez JJ, Delvolvé I, Abrous DN, Le Moal M, Cabelguen JM. Serotonergic systems in the spinal cord of the amphibian urodele Pleurodeles waltl. J Comp Neurol. 2000 Mar;419(1):49-60.

Brustein E, Chong M, Holmqvist B, Drapeau P. Serotonin patterns locomotor network activity in the developing zebrafish by modulating quiescent periods. J Neurobiol. 2003a Dec; 57(3):303-22.

Brustein E, Saint-Amant L, Buss RR, Chong M, McDearmid JR, Drapeau P. Steps during the development of the zebrafish locomotor network. J Physiol Paris. 2003b Jan;97(1): 77-86.

Butler AB, Northcutt RG. Retinal projections in the bowfin, Amia calva: cytoarchitectonic and experimental analysis. Brain Behav Evol. 1992;39(3):169-94. 
Carrera I, Molist P, Anadón R, Rodríguez-Moldes I. Development of the serotoninergic system in the central nervous system of a shark, the lesser spotted dogfish Scyliorhinus canicula. J Comp Neurol. 2008 Dec;511(6):804-31.

Challet E, Miceli D, Pierre J, Repérant J, Masicotte G, Herbin M, et al. Distribution of serotoninimmunoreactivity in the brain of the pigeon (Columba livia). Anat Embryol (Berl). 1996 Mar;193(3):209-27.

Challet E, Pierre J, Repérant J, Ward R, Miceli D. The serotoninergic system of the brain of the viper, Vipera aspis. An immunohistochemical study. J Chem Neuroanat. 1991 Jul-Aug;4(4):233-8.

Chiba A. Neuropeptide Y-immunoreactive (NPY-ir) structures in the brain of the gar Lepisosteus oculatus (Lepisosteiformes, Osteichthyes) with special regard to their anatomical relations to gonadotropin-releasing hormone (GnRH)-ir structures in the hypothalamus and the terminal nerve. Gen Comp Endocrinol. 2005 Jul;142(3):336-46.

Chiba A. Serotonergic neuron system in the spinal cord of the gar Lepisosteus oculatus (Lepisosteiformes, Osteichthyes) with special regard to the juxtameningeal serotonergic plexus as a paracrine site. Neurosci Lett. 2007 Feb; 413(1):6-10.

Chiba A, Oka S. Serotonin-immunoreactive structures in the central nervous system of the garfish Lepisosteus productus (Semionotiformes, Osteichthyes). Neurosci Lett. 1999 Feb;261(1-2):73-6.

Clairambault P, Christophe N, Pairault C, Herbin $\mathrm{M}$, Ward R, Reperant J. Organization of the serotoninergic system in the brain of two amphibian species, Ambystoma mexicanum (Urodela) and Typhlonectes compressicauda (Gymnophiona). Anat Embryol (Berl). 1994 Jul;190(1):87-99.

Collin SP, Northcutt RG. The visual system of the Florida garfish, Lepisosteus platyrhincus (Ginglymodi). IV. Bilateral projections and the binocular visual field. Brain Behav Evol. 1995;45(1):34-53.

Corio M, Peute J, Steinbusch HW. Distribution of serotonin- and dopamine-immunoreactivity in the brain of the teleost Clarias gariepinus. J Chem Neuroanat. 1991 Mar-Apr;4(2):79-95.

Corio M, Thibault J, Peute J. Distribution of catecholaminergic and serotoninergic systems in forebrain and midbrain of the newt, Triturus alpestris (Urodela). Cell Tissue Res. 1992 May;268(2):377-87.

Cornide-Petronio ME, Anadón R, Rodicio MC Barreiro-Iglesias A. The sea lamprey tryptophan hydroxylase: new insight into the evolution of the serotonergic system of vertebrates. Brain Struct Funct. 2013 Mar;218(2): 587-93.

Cozzi B, Viglietti-Panzica C, Aste N, Panzica GC. The serotoninergic system in the brain of the Japanese quail. An immunohistochemical study. Cell Tissue Res. 1991 Feb;263(2):271-84.

Dahlström A, Fuxe K. Localization of monoamines in the lower brain stem. Experientia. 1964 Jul;20(7):398-9.
Dicke U, Wallstein M, Roth G. 5-HT-like immunoreactivity in the brains of plethodontid and salamandrid salamanders (Hydromantes italicus, Hydromantes genei, Plethodon jordani, Desmognathus ochrophaeus, Pleurodeles waltl): an immunohistochemical and biocytin double-labelling study. Cell Tissue Res. 1997 Feb;287(3):513-23.

Dünker N. Serotonergic neurons and processes in the adult and developing retina of Ichthyophis kohtaoensis (Amphibia; Gymnophiona). Anat Embryol (Berl). 1999 Jan;199(1):35-43.

Edwards DH, Kravitz EA. Serotonin, social status and aggression. Curr Opin Neurobiol. 1997 $\operatorname{Dec} ; 7(6): 812-9$.

Ekström P. Developmental changes in the brainstem serotonergic nuclei of teleost fish and neural plasticity. Cell Mol Neurobiol. 1994 Aug;14(4):381-93.

Ekström P, Nyberg L, van Veen T. Ontogenetic development of serotoninergic neurons in the brain of a teleost, the three-spined stickleback. An immunohistochemical analysis. Brain Res. 1985 Jan;349(1-2):209-24.

Ekström P, Van Veen T. Distribution of 5-hydroxytryptamine (serotonin) in the brain of the teleost Gasterosteus aculeatus L. J Comp Neurol. 1984 Jul;226(3):307-20.

Frankenhuis-van den Heuvel TH, Nieuwenhuys R. Distribution of serotonin-immunoreactivity in the diencephalon and mesencephalon of the trout, Salmo gairdneri. Cellbodies, fibres and terminals. Anat Embryol (Berl). 1984; 169(2):193-204.

Gabriel JP, Mahmood R, Kyriakatos A, Söll I, Hauptmann G, Calabrese RL, et al. Serotonergic modulation of locomotion in zebrafish: endogenous release and synaptic mechanisms. J Neurosci. 2009 Aug;29(33):10387-95.

Gaspar P, Lillesaar C. Probing the diversity of serotonin neurons. Philos Trans R Soc Lond B Biol Sci. 2012 Sep;367(1601):2382-94.

Gilland E, Baker R. Conservation of neuroepithelial and mesodermal segments in the embryonic vertebrate head. Acta Anat (Basel). 1993; 148(2-3):110-23.

González A, Morona R, Moreno N, Bandín S, López JM. Identification of striatal and pallidal regions in the subpallium of anamniotes. Brain Behav Evol. 2014;83(2):93-103.

Heijdra YF, Nieuwenhuys R. Topological analysis of the brainstem of the bowfin, Amia calva. J Comp Neurol. 1994 Jan;339(1):12-26.

Huang S, Moody SA. Three types of serotonincontaining amacrine cells in tadpole retina have distinct clonal origins. J Comp Neurol. 1997 Oct;387(1):42-52.

Hughes LC, Ortí G, Huang Y, Sun Y, Baldwin CC, Thompson AW, et al. Comprehensive phylogeny of ray-finned fishes (Actinopterygii) based on transcriptomic and genomic data. Proc Natl Acad Sci USA. 2018 Jun;115(24): 6249-54.

Ikeda H, Goto J. Distribution of monoamine-containing cells in the central nervous system of the chicken. Jpn J Pharmacol. 1971 Dec;21(6): 763-84.
Jacobowitz DM, MacLean PD. A brainstem atlas of catecholaminergic neurons and serotonergic perikarya in a pygmy primate (Cebuella pygmaea). J Comp Neurol. 1978 Feb;177(3): 397-416.

Jacobs BL, Fornal CA. Serotonin and motor activity. Curr Opin Neurobiol. 1997 Dec;7(6):820-5.

Johnston SA, Maler L, Tinner B. The distribution of serotonin in the brain of Apteronotus leptorhynchus: an immunohistochemical study. J Chem Neuroanat. 1990 Nov-Dec;3(6):429-65.

Kah O, Chambolle P. Serotonin in the brain of the goldfish, Carassius auratus. An immunocytochemical study. Cell Tissue Res. 1983;234(2): 319-33.

Kaslin J, Panula P. Comparative anatomy of the histaminergic and other aminergic systems in zebrafish (Danio rerio). J Comp Neurol. 2001 Nov;440(4):342-77.

Kawano E, Takahata Y, Oishi T, Ukena K, Tsutsui K, Tamotsu S. Neural interaction of gonadotropin-regulating hormone immunoreactive neurons and the suprachiasmatic nucleus with the paraventricular organ in the Japanese grass lizard (Takydromus tachydromoides). Zool Sci. 2006 Mar;23(3):277-87.

Khan IA, Thomas P. Immunocytochemical localization of serotonin and gonadotropin-releasing hormone in the brain and pituitary gland of the Atlantic croaker Micropogonias undulatus. Gen Comp Endocrinol. 1993 Aug;91(2):167-80.

Kiehn O, Rostrup E, Møller M. Monoaminergic systems in the brainstem and spinal cord of the turtle Pseudemys scripta elegans as revealed by antibodies against serotonin and tyrosine hydroxylase. J Comp Neurol. 1992 Nov;325(4):527-47.

Li T, Wu SM, Lam DM, Watt CB. Localization of classical neurotransmitters in interneurons of the larval tiger salamander retina. Invest Ophthalmol Vis Sci. 1990 Feb;31(2):262-71.

Lidov HG, Molliver ME. Immunohistochemical study of the development of serotonergic neurons in the rat CNS. Brain Res Bull. 1982 JulDec;9(1-6):559-604.

Lillesaar C. The serotonergic system in fish. J Chem Neuroanat. 2011 Jul;41(4):294-308.

Lillesaar C, Stigloher C, Tannhäuser B, Wullimann MF, Bally-Cuif L. Axonal projections originating from raphe serotonergic neurons in the developing and adult zebrafish, Danio rerio, using transgenics to visualize raphespecific pet1 expression. J Comp Neurol. 2009 Jan;512(2):158-82.

Liu Q, Debski EA. Serotonin-like immunoreactivity in the adult and developing retina of the leopard frog Rana pipiens. J Comp Neurol. 1993 Dec;338(3):391-404.

López JM, González A. Organization of the serotonergic system in the central nervous system of two basal actinopterygian fishes: the Cladistians Polypterus senegalus and Erpetoichthys calabaricus. Brain Behav Evol. 2014;83(1):54-76.

López JM, González A. Comparative analysis of the serotonergic systems in the CNS of two lungfishes, Protopterus dolloi and Neoceratodus forsteri. Brain Struct Funct. 2015 Jan; 220(1):385-405. 
López JM, González A. Organization of the catecholaminergic systems in the brain of lungfishes, the closest living relatives of terrestrial vertebrates. J Comp Neurol. 2017 Oct; 525(14):3083-109.

López JM, Lozano D, Morales L, González A. Pattern of nitrergic neuronal system organization in the brain of two holostean fishes (Actinopterygii: ginglymodi). Brain Behav Evol. 2017;89(2):117-52.

López JM, Lozano D, Morona R, González A. Organization of the catecholaminergic systems in two basal actinopterygian fishes, Polypterus senegalus and Erpetoichthys calabaricus (Actinopterygii: cladistia). J Comp Neurol. 2019 Feb;527(2):437-61.

Lozano D, González A, López JM. Organization of the orexin/hypocretin system in the brain of holostean fishes: assessment of possible relationships with monoamines and neuropeptide Y. Brain Behav Evol. 2018;91(4): 228-51.

Lozano D, Morona R, González A, López JM. Comparative analysis of the organization of the catecholaminergic systems in the brain of holostean fishes (Actinopterygii/neopterygii). Brain Behav Evol. 2019;93(4):206-35.

Lucki I. The spectrum of behaviors influenced by serotonin. Biol Psychiatry. 1998 Aug;44(3): 151-62.

Malz CR, Jahn H, Meyer DL. Centrifugal PheMet-Arg-Phe-NH2-like immunoreactive innervation of the retina in a non-teleost bony fish, Lepisosteus osseus. Neurosci Lett. 1999 Apr;264(1-3):33-6.

Manger PR, Fahringer HM, Pettigrew JD, Siegel JM. The distribution and morphological characteristics of serotonergic cells in the brain of monotremes. Brain Behav Evol. 2002; 60(5):315-32.

Maseko BC, Bourne JA, Manger PR. Distribution and morphology of cholinergic, putative catecholaminergic and serotonergic neurons in the brain of the Egyptian rousette flying fox, Rousettus aegyptiacus. J Chem Neuroanat. 2007 Nov;34(3-4):108-27.

Maurer CM, Schönthaler HB, Mueller KP, Neuhauss SC. Distinct retinal deficits in a zebrafish pyruvate dehydrogenase-deficient $\mathrm{mu}-$ tant. J Neurosci. 2010 Sep;30(36):11962-72.

May PJ. The mammalian superior colliculus: laminar structure and connections. Prog Brain Res. 2006;151:321-78.

Mays JC, Kelly MC, Coon SL, Holtzclaw L, Rath MF, Kelley MW, et al. Single-cell RNA sequencing of the mammalian pineal gland identifies two pinealocyte subtypes and cell type-specific daily patterns of gene expression. PLoS One. 2018 Oct;13(10):e0205883.

McCormick CA. Central projections of the lateral line and eighth nerves in the bowfin, Amia calva. J Comp Neurol. 1981 Mar; 197(1):1-15.

Meek J, Joosten HW. Distribution of serotonin in the brain of the mormyrid teleost Gnathonemus petersii. J Comp Neurol. 1989 Mar; 281(2):206-24.
Meek J, Nieuwenhuys R. Holosteans and teleosts. In: Nieuwenhuys R, Ten Donkelaar HJ, Nicholson C, editors. The central nervous system of vertebrates. Volume 2. Berlin: Springer; 1998. pp. 759-937.

Meneghelli C, Rocha NH, Mengatto V, Hoeller AA, Santos TS, Lino-de-Oliveira C, et al. Distribution of tryptophan hydroxylase-immunoreactive neurons in the brainstem and diencephalon of the pigeon (Columba livia). J Chem Neuroanat. 2009 Sep;38(1):34-46.

Moret F, Guilland JC, Coudouel S, Rochette L, Vernier P. Distribution of tyrosine hydroxylase, dopamine, and serotonin in the central nervous system of amphioxus (Branchiostoma lanceolatum): implications for the evolution of catecholamine systems in vertebrates. J Comp Neurol. 2004 Jan;468(1):135-50.

Morona R, López JM, González A. Localization of calbindin-d28k and calretinin in the brain of dermophis mexicanus (amphibia: gymnophiona) and its bearing on the interpretation of newly recognized neuroanatomical regions. Brain Behav Evol. 2011;77(4):231-69.

Morona R, López JM, Northcutt RG, González A. Comparative analysis of the organization of the cholinergic system in the brains of two holostean fishes, the Florida gar Lepisosteus platyrhincus and the bowfin Amia calva. Brain Behav Evol. 2013;81(2):109-42.

Müller C, Jacobs B, editors. Handbook of behavioral neurobiology of serotonin. London: Academic Press; 2010.

Negishi K, Wagner HJ. Differentiation of photoreceptors, glia, and neurons in the retina of the cichlid fish Aequidens pulcher; an immunocytochemical study. Brain Res Dev Brain Res. 1995 Oct;89(1):87-102.

Nelson JS, Grande TC, Wilson MV. Fishes of the world. 5th ed. New York: Wiley; 2016. https:// doi.org/10.1002/9781119174844.

Nieuwenhuys R. The development and general morphology of the telencephalon of actinopterygian fishes: synopsis, documentation and commentary. Brain Struct Funct. 2011 Jan; 215(3-4):141-57.

Northcutt RG. Localization of neurons afferent to the optic tectum in longnose gars. J Comp Neurol. 1982 Feb;204(4):325-35.

Northcutt RG, Butler AB. Retinofugal pathways in the lingnose gar Lepisosteus osseus (linnaeus). J Comp Neurol. 1976 Mar;166(1):115.

Northcutt RG, Butler AB. Projections of the optic tectum in the longnose gar, Lepisosteus osseus. Brain Res. 1980 May;190(2):333-46.

Northcutt RG, Butler AB. The diencephalon and optic tectum of the longnose gar, Lepisosteus osseus (L.): cytoarchitectonics and distribution of acetylcholinesterase. Brain Behav Evol. 1993;41(2):57-81.

Onstott D, Elde R. Immunohistochemical localization of urotensin $\mathrm{I} /$ corticotropin-releasing factor, urotensin II, and serotonin immunoreactivities in the caudal spinal cord of nonteleost fishes. J Comp Neurol. 1986 Jul;249(2): 205-25.
Osborne NN, Barnett NL. What constitutes a serotonergic neurone in the retina? Neurochem Int. 1990;17(2):177-87.

Parent A. Functional anatomy and evolution of monoaminergic systems. Am Zool. 1984; 24(3):783-90.

Parent A, Northcutt RG. The monoamine-containing neurons in the brain of the garfish, Lepisosteus osseus. Brain Res Bull. 1982 JulDec;9(1-6):189-204.

Pérez MR, Pellegrini E, Cano-Nicolau J, Gueguen MM, Menouer-Le Guillou D, Merot Y, et al. Relationships between radial glial progenitors and 5-HT neurons in the paraventricular organ of adult zebrafish - potential effects of serotonin on adult neurogenesis. Eur J Neurosci. 2013 Nov;38(9):3292-301.

Pierre J, Repérant J, Ward R, Vesselkin NP, Rio JP, Miceli D, et al. The serotoninergic system of the brain of the lamprey, Lampetra fluviatilis: an evolutionary perspective. J Chem Neuroanat. 1992 May-Jun;5(3):195-219.

Piñuela C, Northcutt RG. Immunohistochemical organization of the forebrain in the white sturgeon, Acipenser transmontanus. Brain Behav Evol. 2007;69(4):229-53.

Puelles L, Rubenstein JL. Forebrain gene expression domains and the evolving prosomeric model. Trends Neurosci. 2003 Sep;26(9):46976.

Puelles L, Rubenstein JL. A new scenario of hypothalamic organization: rationale of new hypotheses introduced in the updated prosomeric model. Front Neuroanat. 2015 Mar;9:27.

Rink E, Guo S. The too few mutant selectively affects subgroups of monoaminergic neurons in the zebrafish forebrain. Neuroscience. 2004;127(1):147-54.

Rink E, Wullimann MF. The teleostean (zebrafish) dopaminergic system ascending to the subpallium (striatum) is located in the basal diencephalon (posterior tuberculum). Brain Res. 2001 Jan;889(1-2):316-30.

Ríos H, Brusco A, Pecci Saavedra J. Development of serotoninergic chick retinal neurons. Int J Dev Neurosci. 1997 Oct;15(6):729-38.

Ritchie TC, Livingston CA, Hughes MG, McAdoo DJ, Leonard RB. The distribution of serotonin in the CNS of an elasmobranch fish: immunocytochemical and biochemical studies in the Atlantic stingray, Dasyatis sabina. J Comp Neurol. 1983 Dec;221(4):429-43.

Ritchie TC, Roos LJ, Williams BJ, Leonard RB. The descending and intrinsic serotoninergic innervation of an elasmobranch spinal cord. J Comp Neurol. 1984 Apr;224(3):395-406.

Rodrigues SL, Maseko BC, Ihunwo AO, Fuxe K, Manger PR. Nuclear organization and morphology of serotonergic neurons in the brain of the Nile crocodile, Crocodylus niloticus. J Chem Neuroanat. 2008 Jan;35(1):133-45.

Rodríguez-Gómez FJ, Rendón-Unceta MC, Sarasquete C, Muñoz-Cueto JA. Distribution of serotonin in the brain of the Senegalese sole, Solea senegalensis: an immunohistochemical study. J Chem Neuroanat. 2000 Mar;18(3):103-15. 
Ronan MC, Northcutt RG. The origins of descending spinal projections in lepidosirenid lungfishes. J Comp Neurol. 1985 Nov;241(4): 435-44.

Sako H, Kojima T, Okado N. Immunohistochemical study on the development of serotoninergic neurons in the chick: I. Distribution of cell bodies and fibers in the brain. J Comp Neurol. 1986a Nov;253(1):61-78.

Sako H, Kojima T, Okado N. Immunohistochemical study on the development of serotoninergic neurons in the chick: II. Distribution of cell bodies and fibers in the spinal cord. J Comp Neurol. 1986b Nov;253(1):79-91.

Sano Y, Ueda S, Yamada H, Takeuchi Y, Goto M, Kawata M. Immunohistochemical demonstration of serotonin-containing CSF-contacting neurons in the submammalian paraventricular organ. Histochemistry. 1983; 77(4):423-30.

Schofield SP, Everitt BJ. The organization of indoleamine neurons in the brain of the rhesus monkey (Macaca mulatta). J Comp Neurol. 1981 Apr;197(3):369-83.

Schuette E, Chappell RL. Excitatory amino acids and serotonin uptake blockers reveal two physiologically distinct serotonin systems in the retina of the skate, Raja erinacea. Int J Neurosci. 1998 Jul;95(1-2):115-32.

Schütte M. Serotonergic and serotonin-synthesizing cells of the Xenopus retina. Int J Neurosci. 1994 Sep;78(1-2):67-73.

Smeets WJ, Steinbusch HW. Distribution of serotonin immunoreactivity in the forebrain and midbrain of the lizard Gekko gecko. J Comp Neurol. 1988 May;271(3):419-34.

Song JK, Northcutt RG. Morphology, distribution and innervation of the lateral-line receptors of the Florida gar, Lepisosteus platyrhincus. Brain Behav Evol. 1991a;37(1):10-37.

Song JK, Northcutt RG. The primary projections of the lateral-line nerves of the Florida gar, Lepisosteus platyrhincus. Brain Behav Evol. 1991b;37(1):38-63.

Steinbusch HW. Distribution of serotonin-immunoreactivity in the central nervous system of the rat-cell bodies and terminals. Neuroscience. 1981;6(4):557-618.

Sternberger LA. The unlabeled antibody (PAP) method, introduction. J Histochem Cytochem. 1979 Dec;27(12):1657.
Straka H, Baker R, Gilland E. Preservation of segmental hindbrain organization in adult frogs. J Comp Neurol. 2006 Jan;494(2):228-45.

Stuesse SL, Cruce WL. Immunohistochemical localization of serotoninergic, enkephalinergic, and catecholaminergic cells in the brainstem and diencephalon of a cartilaginous fish, $\mathrm{Hy}$ drolagus colliei. J Comp Neurol. 1991 Jul; 309(4):535-48.

Stuesse SL, Cruce WL. Distribution of tyrosine hydroxylase, serotonin, and leu-enkephalin immunoreactive cells in the brainstem of a shark, Squalus acanthias. Brain Behav Evol. 1992;39(2):77-92.

Stuesse SL, Cruce WL, Northcutt RG. Distribution of tyrosine hydroxylase- and serotoninimmunoreactive cells in the central nervous system of the thornback guitarfish, Platyrhinoidis triseriata. J Chem Neuroanat. 1990 Jan-Feb;3(1):45-58.

Stuesse SL, Cruce WL, Northcutt RG. Localization of serotonin, tyrosine hydroxylase, and leu-enkephalin immunoreactive cells in the brainstem of the horn shark, Heterodontus francisci. J Comp Neurol. 1991a Jun;308(2): 277-92.

Stuesse SL, Cruce WL, Northcutt RG. Serotoninergic and enkephalinergic cell groups in the reticular formation of the bat ray and two skates. Brain Behav Evol. 1991b;38(1):39-52.

Stuesse SL, Stuesse DC, Cruce WL. Raphe nuclei in three cartilaginous fishes, Hydrolagus colliei, Heterodontus francisci, and Squalus acanthias. J Comp Neurol. 1995 Jul;358(3): $414-27$.

Tamotsu S, Samejima M, Suzuki N, Morita Y. Three-dimensional reconstruction of serotonin-immunoreactive photoreceptors in the pineal organ of the river lamprey, Lampetra japonica. Biol Signals. 1997 Jul-Dec;6(4-6): 184-90.

Tan HJ, Miletic V. Bulbospinal serotoninergic pathways in the frog Rana pipiens. J Comp Neurol. 1990 Feb;292(2):291-302.

Törk I. Anatomy of the serotonergic system. Ann N Y Acad Sci. 1990;600:9-34.

Ueda S, Nojyo Y, Sano Y. Immunohistochemical demonstration of the serotonin neuron system in the central nervous system of the bullfrog, Rana catesbeiana. Anat Embryol (Berl). 1984;169(3):219-29.
Ueda S, Takeuchi Y, Sano Y. Immunohistochemical demonstration of serotonin neurons in the central nervous system of the turtle (Clemmys japonica). Anat Embryol (Berl). 1983;168(1):1-19.

van Mier P, Joosten HW, van Rheden R, ten Donkelaar HJ. The development of serotonergic raphespinal projections in Xenopus laevis. Int J Dev Neurosci. 1986;4(5):465-75.

Wai MS, Lorke DE, Zhang A, Kung HF, Yew DT. Study of the spinal cords of the sturgeon Acipenser schrenckii, gar Lepisosteus oculatus, and goldfish Carassius auratus by morphological, immunohistochemical, and biochemical approaches. Microsc Res Tech. 2007 Dec;70(12):1079-90.

Wallén P, Christenson J, Brodin L, Hill R, Lansner A, Grillner S. Mechanisms underlying the serotonergic modulation of the spinal circuitry for locomotion in lamprey. Prog Brain Res. 1989;80:321-7.

Wilhelm M, Zhu B, Gábriel R, Straznicky C. Immunocytochemical identification of serotonin-synthesizing neurons in the vertebrate retina: a comparative study. Exp Eye Res. 1993 Feb;56(2):231-40.

Wolters JG, ten Donkelaar HJ, Steinbusch HW, Verhofstad AA. Distribution of serotonin in the brain stem and spinal cord of the lizard Varanus exanthematicus: an immunohistochemical study. Neuroscience. 1985 Jan; 14(1):169-93.

Wright JJ, David SR, Near TJ. Gene trees, species trees, and morphology converge on a similar phylogeny of living gars (Actinopterygii: Holostei: Lepisosteidae), an ancient clade of rayfinned fishes. Mol Phylogenet Evol. 2012 Jun; 63(3):848-56.

Wullimann MF. The central nervous system. In: Evans DH, editor. The Physiology of Fishes. 2nd ed. Boca Raton: CRC Press LLC; 1998. pp. $245-82$.

Yamada H, Takeuchi Y, Sano Y. Immunohistochemical studies on the serotonin neuron system in the brain of the chicken (Gallus domesticus). I. The distribution of the neuronal somata. Biog Amines. 1984;1:17-28.

Zhu B, Gábriel R, Straznicky C. Serotonin synthesis and accumulation by neurons of the anuran retina. Vis Neurosci. 1992 Sep-Oct;9(34):377-88. 